4

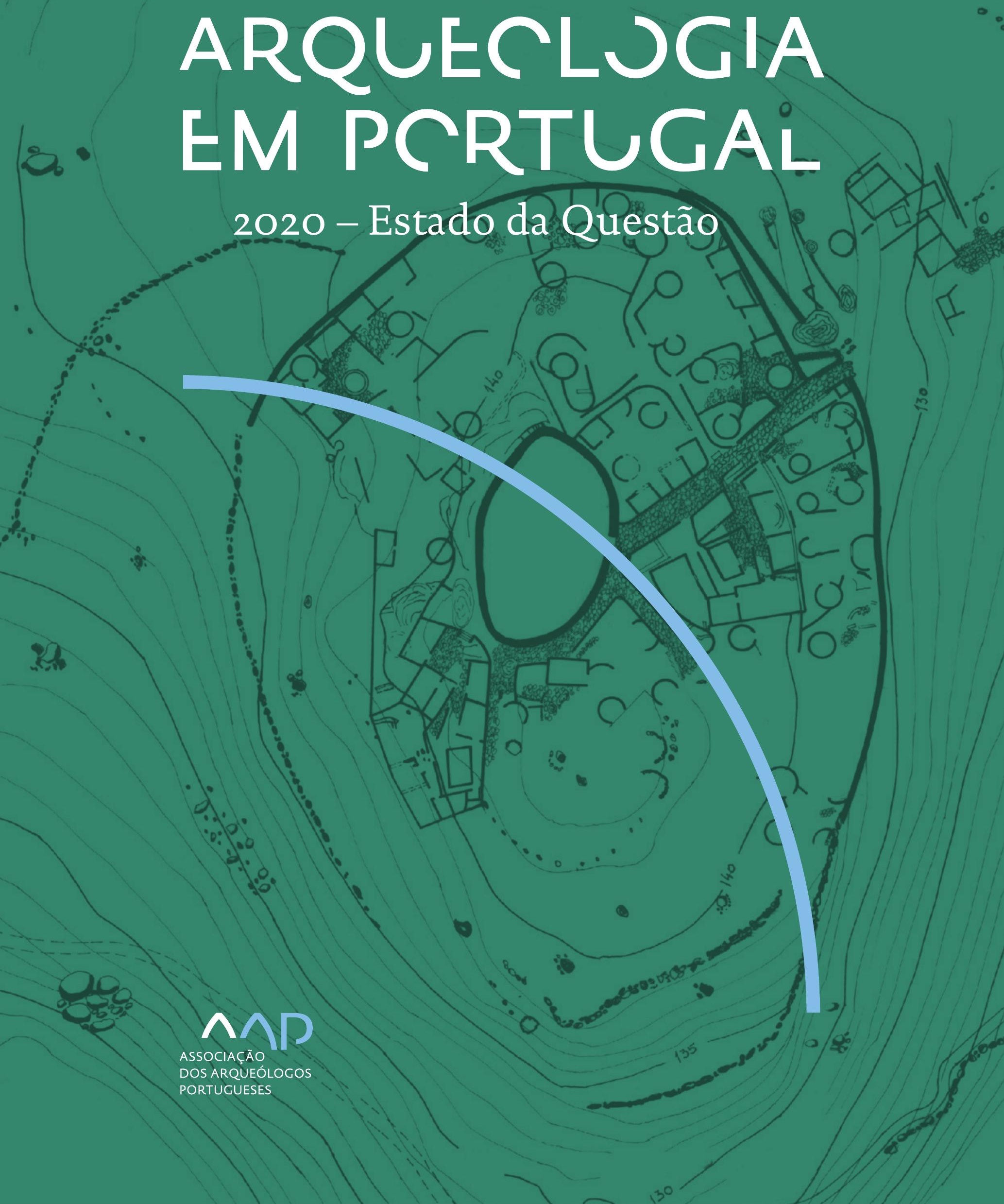


Coordenação editorial: José Morais Arnaud, César Neves e Andrea Martins Design gráfico: Flatland Design

AAP - ISBN: 978-972-9451-89-8

CITCEM - ISBN: 978-989-8970-25-1

Associação dos Arqueólogos Portugueses e CITCEM

Lisboa, 2020

O conteúdo dos artigos é da inteira responsabilidade dos autores. Sendo assim a Associação dos Arqueólogos Portugueses declina qualquer responsabilidade por eventuais equívocos ou questões de ordem ética e legal.

Desenho de capa:

Planta do castro de Monte Mozinho (Museu Municipal de Penafiel).

\section{$\hat{\wedge} \mathrm{P}$}

DOS ARQUEÓLOGOS PORTUGUESES

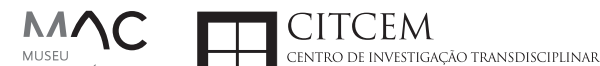
MUSEU
ARQUELLÓGICO
DO CARMO
U.PORTO

FLUP FACULDADE DE LETRAS
UNIVERSIDADE DO PORTO

Apoio

EC para a Ciência 


\section{Índice}

15 Prefácio

José Morais Arnaud

\section{Historiografia e Teoria}

17 Território, comunidade, memória e emoção: a contribuição da história da arqueologia (algumas primeiras e breves reflexões)

Ana Cristina Martins

25 Como descolonizar a arqueologia portuguesa?

Rui Gomes Coelho

41 Arqueologia e Modernidade: uma revisitação pessoal e breve de alguns aspetos da obra homónima de Julian Thomas de 2004

Vítor Oliveira Jorge

57 Dados para a História das Mulheres na Arqueologia portuguesa, dos finais do século XIX aos inícios do século XX: números, nomes e tabelas

Filipa Dimas / Mariana Diniz

73 Retractos da arqueologia portuguesa na imprensa: (in)visibilidades no feminino

Catarina Costeira / Elsa Luís

85 Arqueologia e Arqueólogos no Norte de Portugal Jacinta Bugalhão

101 Vieira Guimarães (1864-1939) e a arqueologia em Tomar: uma abordagem sobre o território e as gentes

João Amendoeira Peixoto / Ana Cristina Martins

115 Os memoráveis? A arqueologia algarvia na imprensa nacional e regional na presente centúria (2001-2019): características, visões do(s) passado(s) e a arqueologia

enquanto marca

Frederico Agosto / João Silva

129 A Evolução da Arqueologia Urbana e a Valorização Patrimonial no Barlavento Algarvio: Os casos de Portimão e Silves

Artur Mateus / Diogo Varandas / Rafael Boavida

\section{Gestão, Valorização e Salvaguarda do Património}

145 O Caderno Reivindicativo e as condições de trabalho em Arqueologia Miguel Rocha / Liliana Matias Carvalho / Regis Barbosa / Mauro Correia / Sara Simões / Jacinta Bugalhão / Sara Brito / Liliana Veríssimo Carvalho / Richard Peace / Pedro Peça / Cézer Santos

155 Os Estudos de Impacte Patrimonial como elemento para uma estratégia sustentável de minimização de impactes no âmbito de reconversões agrícolas Tiago do Pereiro

165 Salvaguarda de Património arqueológico em operações florestais: gestão e sensibilização Filipa Bragança / Gertrudes Zambujo / Sandra Lourenço / Belém Paiva / Carlos Banha / Frederico Tatá Regala / Helena Moura / Jacinta Bugalhão / João Marques / José Correia / Pedro Faria / Samuel Melro

179 Os valores do Património: uma investigação sobre os Sítios Pré-históricos de Arte Rupestre do Vale do Rio Côa e de Siega Verde José Paulo Francisco 
189 Conjugando recursos arqueológicos e naturais para potenciar as visitas ao Geoparque Litoral de Viana do Castelo (Noroeste de Portugal)

Hugo A. Sampaio / Ana M.S. Bettencourt / Susana Marinho / Ricardo Carvalhido

203 Áreas de Potencial Arqueológico na Região do Médio Tejo: Modelo Espacial Preditivo Rita Ferreira Anastácio / Ana Filipa Martins / Luiz Oosterbeek

223 Património Arqueológico e Gestão Territorial: O contributo da Arqueologia para a revisão do PDM de Avis

Ana Cristina Ribeiro

237 A coleção arqueológica do extinto Museu Municipal do Porto - Origens, Percursos e Estudos

Sónia Couto

251 Valpaços - uma nova carta arqueológica

Pedro Pereira / Maria de Fátima Casares Machado

263 Arqueologia na Cidade de Peniche

Adriano Constantino / Luís Rendeiro

273 Arqueologia Urbana: a cidade de Lagos como caso de Estudo Cátia Neto

285 Estratégias de promoção do património cultural subaquático nos Açores. O caso da ilha do Faial

José Luís Neto / José Bettencourt / Luís Borges / Pedro Parreira

297 Carta Arqueológica da Cidade Velha: Uma primeira abordagem

Jaylson Monteiro / Nireide Tavares / Sara da Veiga / Claudino Ramos / Edson Brito /

Carlos Carvalho / Francisco Moreira / Adalberto Tavares

311 Antropologia Virtual: novas metodologias para a análise morfológica e funcional Ricardo Miguel Godinho / Célia Gonçalves

\section{Didáctica da Arqueologia}

327 Como os projetos de Arqueologia podem contribuir para uma comunidade culturalmente mais consciente Alexandra Figueiredo / Claúdio Monteiro / Adolfo Silveira / Ricardo Lopes

337 Educação Patrimonial - Um cidadão esclarecido é um cidadão ativo! Ana Paula Almeida

351 A aproximação da Arqueologia à sala de aula: um caso de estudo no $3^{\circ}$ ciclo do Ensino Básico Luís Serrão Gil

363 Arqueologia 3.o - Pensar e comunicar a Arqueologia para um futuro sustentável Mónica Rolo

377 “Conversa de Arqueólogos" - Divulgar a Arqueologia em tempos de Pandemia Diogo Teixeira Dias

389 Escola Profissional de Arqueologia: desafios e oportunidades Susana Nunes / Dulcineia Pinto / Júlia Silva / Ana Mascarenhas

399 Os Museus de Arqueologia e os Jovens: a oferta educativa para o público adolescente Beatriz Correia Barata / Leonor Medeiros

411 O museu universitário como mediador entre a ciência e a sociedade: o exemplo da secção de arqueologia no Museu de História Natural e da Ciência da Universidade do Porto (MHNC-UP)

Rita Gaspar 
421 Museu de Lanifícios: Real Fábrica de Panos. Atividades no âmbito da Arqueologia Beatriz Correia Barata / Rita Salvado

427 Arqueologia Pública e o caso da localidade da Mata (Torres Novas) Cláudia Manso / Ana Rita Ferreira / Cristiana Ferreira / Vanessa Cardoso Antunes

431 Do sítio arqueológico ao museu: um percurso (também) didático Lídia Fernandes

447 Estão todos convidados para a Festa! E para dançar também... O projecto do Serviço Educativo do Museu Arqueológico do Carmo na $5^{\underline{a}}$ Edição da Festa da Arqueologia Rita Pires dos Santos

459 O “Clã de Carenque”, um projeto didático de arqueologia Eduardo Gonzalez Rocha

469 Mediação cultural: peixe que puxa carroça nas Ruínas Romanas de Troia Inês Vaz Pinto / Ana Patrícia Magalhães / Patrícia Brum / Filipa Santos

481 Didática Arqueológica, experiências do Projeto Mértola Vila Museu Maria de Fátima Palma / Clara Rodrigues / Susana Gómez / Lígia Rafael

\section{Arte Rupestre}

497 Os inventários de arte rupestre em Portugal Mila Simões de Abreu

513 O projeto FIRST-ART - conservação, documentação e gestão das primeiras manifestações de arte rupestre no Sudoeste da Península Ibérica: as grutas do Escoural e Maltravieso Sara Garcês / Hipólito Collado / José Julio García Arranz / Luiz Oosterbeek / António Carlos Silva / Pierluigi Rosina / Hugo Gomes / Anabela Borralheiro Pereira / George Nash / Esmeralda Gomes / Nelson Almeida / Carlos Carpetudo

523 Trabalhos de documentação de arte paleolítica realizados no âmbito do projeto PalæoCôa André Tomás Santos / António Fernando Barbosa / Luís Luís / Marcelo Silvestre / Thierry Aubry

537 Imagens fantasmagóricas, silhuetas elusivas: as figuras humanas na arte do Paleolítico Superior da região do Côa Mário Reis

$55^{1}$ Os motivos zoomórficos representados nas placas de tear de Vila Nova de São Pedro (Azambuja, Portugal) Andrea Martins / César Neves / José M. Arnaud / Mariana Diniz

571 Arte Rupestre do Monte de Góios (Lanhelas, Caminha). Síntese dos resultados dos trabalhos efectuados em 2007-2009 Mário Varela Gomes

599 Gravuras rupestres de barquiformes no Monte de S. Romão, Guimarães, Noroeste de Portugal Daniela Cardoso

613 Círculos segmentados gravados na Bacia do Rio Lima (Noroeste de Portugal): contributos para o seu estudo Diogo Marinho / Ana M.S. Bettencourt / Hugo Aluai Sampaio

631 Equídeos gravados no curso inferior do Rio Mouro, Monção (NW Portugal). Análise preliminar Coutinho, L.M. / Bettencourt, A.M.S / Sampaio, Hugo A.S

645 Paletas na Arte Rupestre do Noroeste de Portugal. Inventário preliminar Bruna Sousa Afonso / Ana M. S. Bettencourt / Hugo A. Sampaio 


\section{Pré-História}

661 O projeto Miño/Minho: balanço de quatro anos de trabalhos arqueológicos Sérgio Monteiro-Rodrigues / João Pedro Cunha-Ribeiro / Eduardo Méndez-Quintas / Carlos Ferreira / Pedro Xavier / José Meireles / Alberto Gomes / Manuel Santonja / Alfredo Pérez-González

677 A ocupação paleolítica da margem esquerda do Baixo Minho: a indústria lítica do sítio de Pedreiras 2 (Monção, Portugal) e a sua integração no contexto regional Carlos Ferreira / João Pedro Cunha-Ribeiro / Sérgio Monteiro-Rodrigues / Eduardo Méndez-Quintas / Pedro Xavier / José Meireles / Alberto Gomes / Manuel Santonja / Alfredo Pérez-González

693 O sítio acheulense do Plistocénico médio da Gruta da Aroeira Joan Daura / Montserrat Sanz / Filipa Rodrigues / Pedro Souto / João Zilhão

703 As sociedades neandertais no Barlavento algarvio: modelos preditivos com recurso aos SIG

Daniela Maio

715 A utilização de quartzo durante o Paleolítico Superior no território dos vales dos rios Vouga e Côa

Cristina Gameiro / Thierry Aubry / Bárbara Costa / Sérgio Gomes / Luís Luís / Carmen Manzano / André Tomás Santos

733 Uma perspetiva diacrónica da ocupação do concheiro do Cabeço da Amoreira (Muge, Portugal) a partir da tecnologia lítica Joana Belmiro / João Cascalheira / Célia Gonçalves

745 Novos dados sobre a Pré-história Antiga no concelho de Palmela. A intervenção arqueológica no sítio do Poceirão I

Michelle Teixeira Santos

757 Problemas em torno de Datas Absolutas Pré-Históricas no Norte do Alentejo Jorge de Oliveira

771 Povoamento pré-histórico nas áreas montanhosas do NO de Portugal: o Abrigo 1 de Vale de Cerdeira Pedro Xavier / José Meireles / Carlos Alves

783 Apreciação do povoamento do Neolítico Inicial na Baixa Bacia do Douro. A Lavra I (Serra da Aboboreira) como caso de estudo Maria de Jesus Sanches

797 O Processo de Neolitização na Plataforma do Mondego: os dados do Sector C do Outeiro dos Castelos de Beijós (Carregal do Sal)

João Carlos de Senna-Martinez / José Manuel Quintã Ventura / Andreia Carvalho / Cíntia Maurício

823 Novos trabalhos na Lapa da Bugalheira (Almonda, Torres Novas) Filipa Rodrigues / Pedro Souto / Artur Ferreira / Alexandre Varanda / Luís Gomes / Helena Gomes / João Zilhão

837 A pedra polida e afeiçoada do sítio do Neolítico médio da Moita do Ourives (Benavente, Portugal)

César Neves

857 Casal do Outeiro (Encarnação, Mafra): novos contributos para o conhecimento do povoamento do Neolítico final na Península de Lisboa.

Cátia Delicado / Carlos Maneira e Costa / Marta Miranda / Ana Catarina Sousa

873 Stresse infantil, morbilidade e mortalidade no sítio arqueológico do Neolítico Final/ Calcolítico ( $4^{\circ}$ e $3^{\circ}$ milénio a.C.) do Monte do Carrascal 2 (Ferreira do Alentejo, Beja) Liliana Matias de Carvalho / Sofia N. Wasterlain 
885 Come together: O Conjunto Megalítico das Motas (Monção, Viana do Castelo) e as expressões Campaniformes do Alto Minho Ana Catarina Basílio / Rui Ramos

899 Trabalhos arqueológicos no sítio Calcolítico da Pedreira do Poio Carla Magalhães / João Muralha / Mário Reis / António Batarda Fernandes

913 O sítio arqueológico de Castanheiro do Vento. Da arquitectura do sítio à arquitectura de um território João Muralha Cardoso

925 Estudo zooarqueológico das faunas do Calcolítico final de Vila Nova de São Pedro (Azambuja, Portugal): Campanhas de 2017 e 2018 Cleia Detry / Ana Catarina Francisco / Mariana Diniz / Andrea Martins / César Neves / José Morais Arnaud

943 As faunas depositadas no Museu Arqueológico do Carmo provenientes de Vila Nova de São Pedro (Azambuja): as campanhas de 1937 a 1967 Ana Catarina Francisco / Cleia Detry / César Neves / Andrea Martins / Mariana Diniz / José Morais Arnaud

959 Análise funcional de material lítico em sílex do castro de Vila Nova de S. Pedro (Azambuja, Portugal): uma primeira abordagem Rafael Lima

971 O recinto da Folha do Ouro 1 (Serpa) no contexto dos recintos de fossos calcolíticos alentejanos

António Carlos Valera / Tiago do Pereiro / Pedro Valério / António M. Monge Soares

\section{Proto-História}

987 Produção de sal marinho na Idade do Bronze do noroeste Português. Alguns dados para uma reflexão

Ana M. S. Bettencourt / Sara Luz / Nuno Oliveira / Pedro P. Simões / Maria Isabel C. Alves / Emílio Abad-Vidal

1001 A estátua-menir do Pedrão ou de São Bartolomeu do Mar (Esposende, noroeste de Portugal) no contexto arqueológico da fachada costeira de entre os rios Neiva e Cávado Ana M. S. Bettencourt / Manuel Santos-Estévez / Pedro Pimenta Simões / Luís Gonçalves

1015 O Castro do Muro (Vandoma/Baltar, Paredes) - notas para uma biografia de ocupação da Idade do Bronze à Idade Média

Maria Antónia D. Silva / Ana M. S. Bettencourt / António Manuel S. P. Silva / Natália Félix

1031 Do Bronze Final à Idade Média - continuidades e hiatos na ocupação de Povoados em Oliveira de Azeméis João Tiago Tavares / Adriaan de Man

1041 As faunas do final da Idade do Bronze no Sul de Portugal: leituras desde o Outeiro do Circo (Beja)

Nelson J. Almeida / Íris Dias / Cleia Detry / Eduardo Porfírio / Miguel Serra

1055 A Espada do Monte das Oliveiras (Serpa) - uma arma do Bronze Pleno do Sudoeste Rui M. G. Monge Soares / Pedro Valério / Mariana Nabais / António M. Monge Soares

1065 São Julião da Branca (Albergaria-a-Velha) - Investigação e valorização de um povoado do Bronze Final

António Manuel S. P. Silva / Paulo A. P. Lemos / Sara Almeida e Silva / Edite Martins de Sá

1083 Do castro de S. João ao Mosteiro de Santa Clara: notícia de uma intervenção arqueológica, em Vila do Conde Rui Pinheiro 
1095 O castro de Ovil (Espinho), um quarto de século de investigação - resultados e questões em aberto

Jorge Fernando Salvador / António Manuel S. P. Silva

1111 O Castro de Salreu (Estarreja), um povoado proto-histórico no litoral do Entre Douro e Vouga

Sara Almeida e Silva / António Manuel S. P. Silva / Paulo A. P. Lemos / Edite Martins de Sá

1127 Castro de Nossa Senhora das Necessidades (Sernancelhe): uma primeira análise artefactual Telma Susana O. Ribeiro

${ }_{1141}$ A cividade de Bagunte. O estado atual da investigação Pedro Brochado de Almeida

1153 Zoomorfos na cerâmica da Idade do Ferro no NW Peninsular: inventário, cronologias e significado Nuno Oliveira / Cristina Seoane

1163 Vasos gregos em Portugal: diferentes maneiras de contar a história do intercâmbio cultural na Idade do Ferro

Daniela Ferreira

1175 Os exotica da necrópole da Idade do Ferro do Olival do Senhor dos Mártires (Alcácer do Sal) no seu contexto regional

Francisco B. Gomes

\section{Antiguidade Clássica e Tardia}

1191 O uso de madeira como combustível no sítio da Quinta de Crestelos (Baixo Sabor): da Idade do Ferro à Romanização Filipe Vaz / João Tereso / Sérgio Simões Pereira / José Sastre / Javier Larrazabal Galarza / Susana Cosme / José António Pereira / Israel Espi

1207 Cultivos de Época Romana no Baixo Sabor: continuidade em tempos de mudança? João Pedro Tereso / Sérgio Simões Pereira / Filipe Santos / Luís Seabra / Filipe Vaz

1221 A casa romana na Hispânia: aplicação dos modelos itálicos nas províncias ibéricas Fernanda Magalhães / Diego Machado / Manuela Martins

1235 As pinturas murais romanas da Rua General Sousa Machado, n. ${ }^{5}$ 1, Chaves José Carvalho

1243 Trás do Castelo (Vale de Mir, Pegarinhos, Alijó) - Uma exploração agrícola romana do Douro

Tony Silvino / Pedro Pereira

1255 A sequência de ocupação no quadrante sudeste de Bracara Augusta: as transformações de uma unidade doméstica Lara Fernandes / Manuela Martins

1263 Os Mosaicos com decoração geométrica e geométrico-vegetalista dos sítios arqueológicos da área do Conuentus Bracaraugustanus. Novas abordagens quanto à conservação, restauro, decoração e datação Maria de Fátima Abraços / Licínia Wrench

1277 “Casa Romana” do Castro de São Domingos (Cristelos, Lousada): Escavação, Estudo e Musealização Paulo André de P. Lemos

1291 A arqueobotânica no Castro de Guifões (Matosinhos, Noroeste de Portugal): O primeiro estudo carpológico

Luís Seabra / Andreia Arezes / Catarina Magalhães / José Varela / João Pedro Tereso 
1305 Um Horreum Augustano na Foz do Douro (Monte do Castelo de Gaia, Vila Nova de Gaia) Rui Ramos

1311 Ponderais romanos na Lusitânia: padrões, formas, materiais e contextos de utilização Diego Barrios Rodríguez

1323 Um almofariz centro-itálico na foz do Mondego

Marco Penajoia

1335 Estruturas romanas de Carnide - Lisboa Luísa Batalha / Mário Monteiro / Guilherme Cardoso

1347 O contexto funerário do sector da "necrópole NO" da Rua das Portas de S. Antão (Lisboa): o espaço, os artefactos, os indivíduos e a sua interconectividade na interpretação do passado Sílvia Loja, José Carlos Quaresma, Nelson Cabaço, Marina Lourenço, Sílvia Casimiro, Rodrigo Banha da Silva, Francisca Alves-Cardoso

${ }_{1361}$ Povoamento em época Romana na Amadora - resultados de um projeto pluridisciplinar Gisela Encarnação / Vanessa Dias

1371 A Arquitectura Residencial em Mirobriga (Santiago do Cacém): contributo a partir de um estudo de caso Filipe Sousa / Catarina Felício

${ }_{1385}$ O fim do ciclo. Saneamento e gestão de resíduos nos edifícios termais de Mirobriga (Santiago do Cacém)

Catarina Felício / Filipe Sousa

1399 Balsa, Topografia e Urbanismo de uma Cidade Portuária Vítor Silva Dias / João Pedro Bernardes / Celso Candeias / Cristina Tété Garcia

1413 No Largo das Mouras Velhas em Faro (2017): novas evidências da necrópole norte de Ossonoba e da sua ocupação medieval Ricardo Costeira da Silva / Paulo Botelho / Fernando Santos / Liliana Nunes

1429 Instrumentos de pesca recuperados numa fábrica de salga em Ossonoba (Faro) Inês Rasteiro / Ricardo Costeira da Silva / Paulo Botelho

1439 A Necrópole Romana do Eirô, Duas Igrejas (Penafiel): intervenção arqueológica de 2016 Laura Sousa / Teresa Soeiro

1457 Ritual, descarte ou afetividade? A presença de Canis lupus familiaris na Necrópole Noroeste de Olisipo (Lisboa)

Beatriz Calapez Santos / Sofia Simões Pereira / Rodrigo Banha da Silva / Sílvia Casimiro / Cleia Detry / Francisca Alves Cardoso

1467 Dinâmicas económicas em Bracara na Antiguidade Tardia Diego Machado / Manuela Martins / Fernanda Magalhães / Natália Botica

1479 Cerâmicas e Vidros da Antiguidade Tardia do Edifício sob a Igreja do Bom Jesus (Vila Nova de Gaia) Joaquim Filipe Ramos

1493 Novos contributos para a topografia histórica de Mértola no período romano e na Antiguidade Tardia Virgílio Lopes

\section{8. Época Medieval}

1511 Cerâmicas islâmicas no Garb setentrional "português": algumas evidências e incógnitas Constança dos Santos / Helena Catarino / Susana Gómez / Maria José Gonçalves / Isabel Inácio / Gonçalo Lopes / Jacinta Bugalhão / Sandra Cavaco / Jaquelina Covaneiro / Isabel Cristina Fernandes / Ana Sofia Gomes 
1525 Contributo para o conhecimento da cosmética islâmica, em Silves, durante a Idade Média Rosa Varela Gomes

1537 Yábura e o seu território - uma análise histórico-arqueológica de Évora entre os séculos VIII-XII José Rui Santos

1547 A encosta sul do Castelo de Palmela - resultados preliminares da escavação arqueológica Luís Filipe Pereira / Michelle Teixeira Santos

1559 A igreja de São Lourenço (Mouraria, Lisboa): um conjunto de silos e de cerâmica medieval islâmica

Andreia Filipa Moreira Rodrigues

1571 O registo material de movimentações populacionais no Médio Tejo, durante os séculos XII-XIII. Dois casos de "sunken featured buildings", nos concelhos de Cartaxo e Torres Novas Marco Liberato / Helena Santos / Nuno Santos

1585 O nordeste transmontano nos alvores da Idade média. Notas para reflexão Ana Maria da Costa Oliveira

1601 Sepulturas escavadas na rocha do Norte de Portugal e do Vale do Douro: primeiros resultados do Projecto SER-NPVD

Mário Jorge Barroca / César Guedes / Andreia Arezes / Ana Maria Oliveira

1619 "Portucalem Castrum Novum" entre o Mediterrâneo e o Atlântico: o estudo dos materiais cerâmicos alto-medievais do arqueossítio da rua de D. Hugo, nํ. 5 (Porto) João Luís Veloso

1627 A Alta Idade Média na fronteira de Lafões: notas preliminares sobre a Arqueologia no Concelho de Vouzela

Manuel Luís Real / Catarina Tente

1641 Um conjunto cerâmico medieval fora de portas: um breve testemunho aveirense Susana Temudo

${ }_{1651}$ Os Lóios do Porto: uma perspetiva integrada no panorama funerário da Baixa Idade Média à Época Moderna em meios urbanos em Portugal

Ana Lema Seabra

1659 O Caminho Português Interior de Santiago como eixo viário na Idade Média Pedro Azevedo

1665 Morfologia Urbana: Um exercício em torno do Castelo de Ourém André Donas-Botto / Jaqueline Pereira

1677 Intervenção arqueológica na Rua Marquês de Pombal/Largo do Espírito Santo (Bucelas, Loures)

Florbela Estêvão / Nathalie Antunes-Ferreira / Dário Ramos Neves / Inês Lisboa

1691 O Cemitério Medieval do Poço do Borratém e a espacialidade funerária na cidade de Lisboa Inês Belém / Vanessa Filipe / Vasco Noronha Vieira / Sónia Ferro / Rodrigo Banha da Silva

1705 Um Espaço Funerário Conventual do séc. XV em Lisboa: o caso do Convento de São Domingos da Cidade Sérgio Pedroso / Sílvia Casimiro / Rodrigo Banha da Silva / Francisca Alves Cardoso

\section{9. Época Moderna e Contemporânea}

1721 Arqueologia Moderna em Portugal: algumas reflexões críticas em torno da quantificação de conjuntos cerâmicos e suas inferências históricas e antropológicas Rodrigo Banha da Silva / André Bargão / Sara da Cruz Ferreira

1733 Faianças de dois contextos entre os finais do século XVI e XVIII do Palácio dos Condes de Penafiel, Lisboa

Martim Lopes / Tomás Mesquita 
1747 Um perfil de consumo do século XVIII na foz do Tejo: O caso do Mercado da Ribeira, Lisboa Sara da Cruz Ferreira / Rodrigo Banha da Silva / André Bargão

1761 Os Cachimbos dos Séculos XVII e XVIII do Palácio Mesquitela e Convento dos Inglesinhos (Lisboa)

Inês Simão / Marina Pinto / João Pimenta / Sara da Cruz Ferreira / André Bargão / Rodrigo Banha da Silva

1775 "Tomar os fumos da erua que chamão em Portugal erua sancta». Estudo de Cachimbos provenientes da Rua do Terreiro do Trigo, Lisboa

Miguel Martins de Sousa / José Pedro Henriques / Vanessa Galiza Filipe

1787 Cachimbos de Barro Caulínitico da Sé da Cidade Velha (República de Cabo Verde)

Rodrigo Banha da Silva / João Pimenta / Clementino Amaro

1801 Algumas considerações sobre espólio não cerâmico recuperado no Largo de Jesus (Lisboa) Carlos Boavida

1815 Adereços de vidro, dos séculos XVI-XVIII, procedentes do antigo Convento de Santana de Lisboa (anéis, braceletes e contas)

Joana Gonçalves / Rosa Varela Gomes / Mário Varela Gomes

1837 Da ostentação, luxo e poder à simplicidade do uso quotidiano: arqueologia e simbologia de joias e adornos da Idade Moderna Portuguesa Jéssica Iglésias

1849 Os amuletos em Portugal - dos objetos às superstições: o coral vermelho Alexandra Vieira

1865 Cerâmicas de Vila Franca de Xira nos séculos XV e XVI Eva Pires

1879 «Não passa por teu o que me pertence». Marcas de individualização associadas a faianças do Convento de Nossa Senhora de Aracoeli, Alcácer do Sal Catarina Parreira / Íris Fragoso / Miguel Martins de Sousa

1891 Cerâmica de Leiria: alguns focos de produção

Jaqueline Pereira / André Donas-Botto

1901 Os Fornos na Rua da Biquinha, em Óbidos Hugo Silva / Filipe Oliveira

1909 A casa de Pêro Fernandes, contador dos contos de D. Manuel I: o sítio arqueológico da Silha do Alferes, Seixal (século XVI) Mariana Nunes Ferreira

1921 O Alto da Vigia (Sintra) e a vigilância e defesa da costa Alexandre Gonçalves / Sandra Santos

1937 O contexto da torre sineira da Igreja de Santa Maria de Loures Paulo Calaveira / Martim Lopes

1949 A Necrópole do Hospital Militar do Castelo de São Jorge e as práticas funerárias na Lisboa de Época Moderna Susana Henriques / Liliana Matias de Carvalho / Ana Amarante / Sofia N. Wasterlain

1963 SAND - Sarilhos Grandes Entre dois Mundos: o adro da Igreja e a Paleobiologia dos ossos humanos recuperados

Paula Alves Pereira / Roger Lee Jesus / Bruno M. Magalhães

1975 Expansão urbana da vila de Cascais no século XVII e XVIII: a intervenção arqueológica na Rua da Vitória no 15 a 17

Tiago Pereira / Vanessa Filipe

1987 Novos dados para o conhecimento do Urbanismo de Faro em época Moderna Ana Rosa 
1995 Um exemplo de Arqueologia Urbana em Alcoutim: o Antigo Edifício dos CTT Marco Fernandes / Marta Dias / Alexandra Gradim / Virgílio Lopes / Susana Gómez Martínez

2007 Palácio dos Ferrazes (Rua das Flores/Rua da Vitória, Porto): a cocheira de Domingos Oliveira Maia

Francisco Raimundo

2021 As muitas vidas de um edifício urbano: História, Arqueologia e Antropologia no antigo Recreatório Paroquial de Penafiel Helena Bernardo / Jorge Sampaio / Marta Borges

2035 O convento de Nossa Senhora da Esperança de Ponta Delgada: o contributo da arqueologia para o conhecimento de um monumento identitário João Gonçalves Araújo / N’Zinga Oliveira

2047 Arqueologia na ilha do Corvo... em busca da capela de Nossa Senhora do Rosário Tânia Manuel Casimiro / José Luís Neto / Luís Borges / Pedro Parreira

2059 Perdidos à vista da Costa. Trabalhos arqueológicos subaquáticos na Barra do Tejo Jorge Freire / José Bettencourt / Augusto Salgado

2071 Arqueologia marítima em Cabo Verde: enquadramento e primeiros resultados do projecto CONCHA

José Bettencourt / Adilson Dias / Carlos Lima / Christelle Chouzenoux / Cristóvão Fonseca / Dúnia Pereira / Gonçalo Lopes / Inês Coelho / Jaylson Monteiro / José Lima / Maria Eugénia Alves / Patrícia Carvalho / Tiago Silva

2085 Trabalhos arqueológicos na Cidade Velha (Ribeira Grande de Santiago, Cabo Verde): reflexões sobre um projecto de investigação e divulgação patrimonial André Teixeira / Jaylson Monteiro / Mariana Mateus / Nireide Tavares / Cristovão Fonseca / Gonçalo C. Lopes / Joana Bento Torres / Dúnia Pereira / André Bargão / Aurélie Mayer / Bruno Zélie / Carlos Lima / Christelle Chouzenoux / Inês Henriques / Inês Pinto Coelho / José Lima / Patrícia Carvalho / Tiago Silva

2103 A antiga fortificação de Quelba / Khor Kalba (E.A.U.). Resultados de quatro campanhas de escavações, problemáticas e perspectivas futuras Rui Carita / Rosa Varela Gomes / Mário Varela Gomes / Kamyar Kamyad

2123 Colónias para homens novos: arqueologia da colonização agrária fascista no noroeste ibérico Xurxo Ayán Vila / José Mạ . Señorán Martín 


\title{
SEPULTURAS ESCAVADAS NA ROCHA DO NORTE DE PORTUGAL E DO VALE DO DOURO: PRIMEIROS RESULTADOS DO PROJECTO SER-NPVD
}

\author{
Mário Jorge Barroca ${ }^{1}$, César Guedes ${ }^{2}$, Andreia Arezes ${ }^{3}$, Ana Maria Oliveira ${ }^{4}$
}

\begin{abstract}
RESUMO
Apresentam-se os resultados preliminares do projecto «Sepulturas escavadas na rocha do Norte de Portugal e do Vale do Douro" (SER-NPVD)", que se propôs sistematizar a informação sobre as sepulturas rupestres do Norte de Portugal, abarcando as duas margens do vale do Douro e todo o espaço a norte deste rio. Esboça-se uma primeira caracterização das estações identificadas e das sepulturas que as constituem, sendo abordadas as suas principais características e o tipo de espaço funerário em que se inserem. Procura-se também apresentar uma primeira leitura da integração paisagística destes monumentos e da sua relação com alguns dos elementos estruturadores do povoamento.
\end{abstract}

Palavras-chave: Sepulturas escavadas na rocha, Norte de Portugal, Idade Média.

\begin{abstract}
In this text, we present the preliminary results of the project "Rock-cut graves from Northern Portugal and the Douro Valley (SER-NPVD)", a project that intends to systematize the information about the rock graves in the North of Portugal, covering both banks of the Douro valley and the entire territory located north of this river. We also present an outline of the identified sites and correlated graves, approaching their main features and the type of funerary space in which they are inserted. Furthermore, we propose a first insight focused both on the integration of these monuments in the landscape, and on their relation with some of the structuring patterns of settlement.
\end{abstract}

Keywords: Rock Cut graves, Northen Portugal, Middle Ages.

\section{APRESENTAÇÃO 5}

O projecto "Sepulturas Escavadas na Rocha do Norte de Portugal e do Vale do Douro" (SER-NPVD) surgiu em 2018, na sequência da realização do Congresso Internacional «Sepulturas Escavadas na Rocha da Fachada Atlântica da Península Ibérica», uma co-organização da FLUP e do CITCEM (Centro de Investigação Transdisciplinar "Cultura, Espaço e Memória»), que decorreu na Faculdade de Letras da
Universidade do Porto, entre os dias 19 e 20 de outubro de 2017. Por essa altura, os signatários deste texto entenderam que não se devia deixar esmorecer a dinâmica que se tinha gerado e que se podia - e devia - avançar para uma plataforma de trabalho distinta. Nesse sentido, no âmbito do Grupo de Investigação "Territórios e Paisagens» do CITCEM, apresentaram a este Centro de Investigação uma proposta para desenvolver uma plataforma, a ser disponibilizada on line, que fornecesse aos arqueólogos portu-

\footnotetext{
1. FLUP/CITCEM; mbarroca@letras.up.pt

2. CITCEM; cesarlguedes@gmail.com

3. FLUP/CITCEM; aarezes@letras.up.pt

4. CITCEM/FCT; anamcostaoliveira@gmail.com

5. Os autores não seguem o Acordo Ortográfico.
} 
gueses uma sistematização de todas as informações relativas a sepulturas escavadas na rocha do Norte de Portugal. Este projecto de investigação, que recebeu o acrónimo "SER-NPVD", mereceu, desde a primeira hora, o acolhimento e apoio da direcção do CITCEM, o que nos apraz registar aqui, deixando o nosso testemunho público de reconhecimento pela disponibilização dos meios materiais e logísticos que permitiram levar a cabo esta iniciativa ${ }^{6}$.

\section{O PROJECTO E A ÁREA DE ESTUDO}

A proposta formulada foi, portanto, a de sistematizar, em ficha padronizada, todos os dados disponíveis para sepulturas escavadas na rocha do norte de Portugal.

O âmbito geográfico do projecto abrangeu todos os concelhos localizados a Norte do rio Douro, repartidos pelos distritos de Viana do Castelo, Braga, Porto, Vila Real e Bragança, num total de 68 municípios. Mas, porque se entendeu que o vale do rio Douro constituía uma unidade geográfica e histórica, sendo as suas margens indissociáveis, a opção foi a de englobar, igualmente, todos os concelhos que confinam com a margem sul deste rio. Estes concelhos, que se repartem pelos distritos de Aveiro, Viseu e Guarda, foram considerados em toda a sua área, com uma única excepção - o concelho de Santa Maria da Feira, que foi apenas considerado na zona mais a norte, nomeadamente a freguesia de Canedo. Procurou-se, desta forma, obter uma mancha geográfica que fosse coesa e coerente, abrangendo as duas margens do rio Douro e todo o espaço a norte deste rio. A área inventariada corresponde, ao todo, a perto de $20.400 \mathrm{~km}^{2}$ (Quadro 1).

O projecto SER-NPVD incide, assim, sobre um território que, do ponto de vista administrativo, abarca oito distritos, 78 concelhos e 1.928 freguesias. Neste âmbito, o rio Douro apresenta-se como o elemento geomorfológico, dotado de inequívoca espessura histórica, que norteia a constituição desta "unidade" de estudo. Com efeito, ela compreende as áreas concelhias que se espraiam a norte do seu curso, estendendo-se até à actual linha de fronteira política com Espanha e, a sul, as que com ele confinam de modo directo.
Não se trata, pois, de um território homogéneo, mas antes de um espaço marcado por especificidades várias, notórias ao nível da grande variabilidade hipsométrica e da própria constituição geológica, o que se reflecte, necessariamente, na organização da paisagem e da ocupação humana, apenas para sinalizar alguns vectores mais impactantes. Se considerarmos, por exemplo, o relevo e, consequentemente, as altitudes atingidas em diversos pontos do espaço em análise, constatamos não apenas a existência de evidentes variáveis naturais como, em paralelo, a vigência de padrões diferenciados de implantação das sepulturas, ou mesmo a tendência para uma articulação mais reiterada de certas tipologias de estruturas com determinadas áreas geográficas. Por seu turno, a constituição geológica, ao definir o substrato rochoso predominante, teve uma evidente implicação nas diferentes modalidades de enterramentos adoptadas pelas comunidades humanas e ajuda a compreender melhor a distribuição espacial dos sepulcros.

A opção tomada teve, ainda, em atenção a área estudada por um projecto semelhante, coordenado por Catarina Tente, na Faculdade de Ciências Sociais e Humanas da Universidade Nova de Lisboa, e que estudou a região do Centro de Portugal7 7 . Desta forma, procurou-se evitar sobreposições geográficas desnecessárias. Graças a estas duas bases de dados, Portugal ficou dotado de instrumentos de pesquisa que cobrem uma parte significativa do seu espaço territorial. Esta é, julgamos nós, uma situação inédita em termos peninsulares.

Os dados obtidos pelo Projecto SER-NPVD estão disponibilizados on-line, através do link: http:// web2.letras.up.pt/citcem/sepulturas/home.

Importa sublinhar que esta plataforma de pesquisa não é encarada como um projecto encerrado. Pelo contrário, assumimos que um projecto desta natureza estará sempre em construção. Neste sentido, será assegurada a manutenção e actualização de dados na plataforma, pelo que todos os contributos serão bem-vindos. Na página do projecto encontra-se o endereço para o qual podem ser enviados novos dados, que, depois de validados, serão contemplados em actualizações futuras.

\footnotetext{
7. Cf. Pereira, 2015; Tente, 2015; Tente, 2017.
}

6. A apresentação do Projecto encontra-se em https:// www.citcem.org/projeto/36. 


\section{AS SEPULTURAS ESCAVADAS NA ROCHA DO NORTE DE PORTUGAL E DO VALE DO DOURO}

Feita a apresentação do projecto SER-NPVD e da área de estudo, procuraremos de seguida apresentar as primeiras, e ainda muito preliminares, leituras sobre as sepulturas escavadas na rocha do Norte de Portugal e do Vale do Douro. Porém, antes de avançarmos para a análise dos dados propriamente ditos, referiremos apenas algumas das opções metodológicas utilizadas na construção da base de dados que serve de suporte a estas leituras.

A base de dados é constituída por duas fichas de registo interrelacionáveis. Uma ficha é dedicada às estações arqueológicas com presença de sepulturas escavadas na rocha e a outra debruça-se especificamente sobre as características individuais de cada sepulcro. A primeira, que designámos «Ficha de $\mathrm{Ne}-$ crópole», corresponde, portanto, a uma "Ficha de Sítio» e é uma ficha única. A segunda, que chamámos "Ficha de Sepultura», corresponde a uma "Ficha de Monumento» e existem tantas quanto o número de sepulcros que integram uma determinada estação arqueológica.

A «Ficha de Necrópole» reúne as informações sobre as estações arqueológicas, procurando sistematizar os dados relativos à sua localização, ao número de sepulturas que a constituem e se são compostas apenas por sepulturas escavadas na rocha, ou se estas se associam a outras tipologias de enterramento. Para além destas características, procura também, sempre que possível, registar a tipologia de espaço funerário de cada estação e as suas relações com os elementos estruturadores do povoamento, isto é, se se relacionam directamente com locais de habitat, templos, povoados fortificados, castelos ou vias de comunicação. A sistematização dos dados relativos às estações, sobretudo a definição da tipologia de espaço funerário, seguiu o modelo preconizado por Inãki Martin Viso e que tem vindo a ser aplicado nos estudos realizados na região da Beira Alta por Catarina Tente ${ }^{8}$ e outros investigadores. Esta opção metodológica possibilitará, no futuro, a realização de leituras integradas dos espaços funerários existentes tanto a Norte, como a Sul do rio Douro, numa

8. Sobre a definição das tipologias de espaços funerários, cf. Martin Viso, 2012a, pp. 170-173. Vd. tb. Martin Viso, 2012b e Martin Viso, 2016. vasta área que se prolonga até aos contrafortes da Serra da Estrela.

A «Ficha de Sepultura», por seu turno, regista os dados arqueográficos de cada sepulcro, contendo campos destinados à recolha de informações sobre o estado de conservação, as características morfo-tipológicas, a orientação ou alinhamento geográfico e, claro, as suas dimensões.

A recolha de informação foi realizada essencialmente a partir de trabalhos académicos, cartas arqueológicas, monografias locais e relatórios arqueológicos. Recorremos também a alguns recursos on-line, como o Portal do Arqueólogo ou as Cartas Patrimoniais integrantes dos PDM's, frequentemente disponíveis para consulta nos sítios de internet dos municípios. No final de cada "Ficha de Necrópole», no campo Bibliografia, são referidos os trabalhos que serviram de base ao preenchimento dos dados. Este campo não pretende elencar toda a produção bibliográfica sobre cada estação arqueológica, às vezes muito extensa, mas apenas referir as obras utilizadas na constituição da base de dados, a partir das quais se retiraram os dados. Salvaguardou-se, assim, também a autoria científica dos elementos arrolados.

Passando para a análise breve das informações recolhidas, o levantamento bibliográfico realizado permitiu, até ao momento, identificar um conjunto de 386 estações, constituídas por 1.170 sepulcros (Mapa 1).

No que respeita ao estado de conservação, a maioria destas sepulturas preserva-se inteira, mas sem tampa (532 sepulcros, ou seja $45,5 \%$ ), enquanto que apenas 35 sepulturas conservam a respectiva tampa $(3 \%)$. As sepulturas inacabadas ascendem a 28 casos $(2,4 \%)$, fornecendo dados sobre a técnica de execução das sepulturas rupestres, ao mesmo tempo que suscitam uma rica problemática, subjacente aos motivos por que foi abandonada a sua execução. As sepulturas que foram totalmente destruídas ascendem a 91 casos ( $7,8 \%)$, as parcialmente destruídas a 180 ca$\operatorname{sos}(15,4 \%)$, enquanto que não foram localizadas 140 sepulturas $(11,9 \%)$ e 164 não eram visíveis $(14,0 \%)$. Entre as sepulturas que chegaram até nós, a grande maioria foi escavada no substrato geológico granítico, correspondendo a 294 estações $(76,2 \%)$. Este valor não deve causar admiração, porque, como se sabe, o substrato granítico é o predominante na zona estudada. A segunda mancha geológica mais significativa corresponde aos xistos. As sepulturas abertas nesta rocha metamórfica compreendem 48 
locais e constituem apenas $12,4 \%$ do total. Para a discrepância entre estes dois grupos concorre o facto de as manchas xistosas corresponderem a uma área significativamente menor do que as áreas graníticas. Por outro lado, os substratos xistosos originam terrenos mais pobres e menos produtivos que os terrenos graníticos, que, porque têm lençóis freáticos mais superficiais, dão origem a solos mais ricos e produtivos. Isto explica que as manchas xistosas sejam, sistematicamente, áreas com menor densidade populacional e, logo, menos testemunhos arqueológicos, nomeadamente funerários. Isso transparece, até, na dimensão geográfica das paróquias de uma e outra mancha geológica. Mas devemos ainda registar os problemas de conservação diferencial. Com efeito, o xisto é um suporte mais frágil e sujeito a uma maior e mais rápida erosão, o que pode ter contribuído para acentuar a desproporção percentual que se verifica entre as sepulturas abertas no granito e as escavadas no xisto, que poderia, na origem, não ser tão pronunciada. No Norte de Portugal encontramos, ainda, pequenas áreas de quartzitos e de arenitos, mas não conhecemos referências a sepulcros criados nestas rochas. De resto, saindo fora da hegemonia dos granitos e dos xistos, apenas se regista uma sepultura aberta noutro suporte - o saibro, que é, no fundo, um produto resultante da alteração do granito 9 . Registemos, por fim, a ausência de sepulcros abertos no calcário, substrato rochoso ausente no espaço considerado pelo projecto SER-NPVD, dominado pelos granitos e, em menor proporção, pelos xistos, o que contrasta, desde já, com a área do Centro de Portugal. A bibliografia consultada revelou-se omissa quanto ao suporte geológico de 44 locais onde foram abertas as restantes sepulturas (11,4\%).

As estações registadas são, na sua grande maioria, constituídas exclusivamente por sepulturas escavadas na rocha (Mapa 2). A este tipo correspondem 315 sítios (ou seja, 81,6\% do total). Todavia, em alguns casos verifica-se a convivência entre este tipo de sepulcros e outras formas de enterramento medievais, como as sepulturas delimitadas por lajes, registada em 21 sítios (5,4\%), ou os sarcófagos, como ocorre em sete estações $(1,8 \%)$, ou então com ambas as tipologias, verificando-se esta situação apenas em seis locais $(1,6 \%)$. Nos casos em que a bibliografia refere a

9. Trata-se de uma sepultura da Igreja do Bom Jesus de Gaia (CNS5832 do Portal do Arqueólogo). existência de outros tipos de enterramentos associados às sepulturas escavadas na rocha, mas que não é explícita quanto à sua tipologia, optamos por incluir estas estações no grupo "Necrópole Indeterminada". Estas situações totalizam 9,6\% das estações (37 sítios). A seu tempo estas situações poderão ser aclaradas, diminuindo-se o peso percentual destes casos. Os espaços funerários são maioritariamente constituídos por sepulturas escavadas na rocha isoladas ou integradas em núcleos de 2 a 5 sepulturas, totalizando $63,7 \%$ dos sítios (Mapa 3). No caso das sepulturas isoladas contabilizamos 121 sítios $(31,3 \%)$ e os núcleos de 2 a 5 sepulturas são 125 (32,4\%). Ou seja, confirma-se plenamente a ideia de que, no Norte de Portugal, a maioria das sepulturas escavadas na rocha aparecem isoladas ou associadas em conjuntos muito limitados, que dificilmente podem corresponder a "necrópoles" de povoados. As necrópoles constituídas por 6 a 10 monumentos correspondem a $8 \%$ do total, verificando-se a existência de 31 estações deste tipo. As necrópoles desordenadas, para usar a expressão de Iñaki Martin Viso, i.e. as que são compostas por mais de dez monumentos, em que as sepulturas se distribuem pelo espaço de uma forma aparentemente aleatória, sem estarem polarizadas em torno de edifícios de culto, implantando-se isoladas ou em pequenos núcleos, correspondem somente a $3,1 \%$ das estações (12 locais) ${ }^{10}$. No que concerne aos espaços cemiteriais associados a igrejas, verificamos que apenas $8 \%$ dos sítios inventariados se enquadram nesta tipologia (31 sítios). As situações em que não foi possível aferir claramente a tipologia de espaço funerário em que os monumentos se inserem totalizam 17,1\% e dizem respeito a 66 espaços de enterramento.

Como referimos anteriormente, as 386 estações identificadas são constituídas por 1.170 sepulcros. A grande maioria das sepulturas (730) destinava-se a receber indivíduos adultos. Contudo existem 50 sepulturas que, pelas suas dimensões, terão provavelmente sido criadas para receber inumações subadultas. Em 373 casos, o estado de conservação dos sepulcros ou a ausência de informação na bibliografia impediu aferir se os monumentos se destinavam a adultos ou a inumações subadultas.

Entre as diferentes tipologias de sepultura, as de configuração antropomórfica são as mais numerosas, contando com 525 exemplares e corresponden-

10. Cf. Martin Viso, 2012a, p. 171. 
do a $44,9 \%$ do total. As mais representativas são as que apresentam cabeceira rectangular, com 110 sepulturas $(20,9 \%)$, logo seguidas pelas de arco peraltado, com 63 exemplares (12,0\%), pelas de arco de volta perfeita, com 51 monumentos $(9,7 \%)$, e de arco ultrapassado, com 39 monumentos $(7,4 \%)$. As soluções menos frequentes são as que apresentam cabeceiras angulosas ou trapezoidais, com somente nove exemplares $(1,7 \%)$, e as cabeceiras assimétricas, apenas representadas por seis sepulcros (1,1\%). Infelizmente, o conjunto mais numeroso refere-se aos sepulcros em que não foi possível aferir de forma rigorosa a tipologia da sua cabeceira, correspondendo a 247 monumentos e a $47 \%$ do total de monumentos de contornos antropomórficos. Esperamos que, futuros desenvolvimentos desta plataforma permitam, também aqui, reduzir o peso percentual deste grupo de indefinição. Em todo o caso, afigura-se interessante constatar que os túmulos com cabeceira de arco ultrapassado surjam em quarto lugar no conjunto dos monumentos com tipologia de cabeceira definida. Registemos, ainda, um pequeno, mas significativo, grupo de túmulos antropomórficos com desnível entre a cabeceira e o corpo, criando um apoio para o occipital. Este tipo, que aparentemente corresponde ao século XI, regista-se em 48 sepulcros $(4,1 \%)$, enquanto que 325 sepulturas não apresentam qualquer desnível (27,8\%).

As sepulturas de configuração não antropomórfica representam 32,5\% do total de monumentos identificados, correspondendo a 380 sepulturas. Ou seja, grosso modo um terço dos sepulcros rupestres do Norte de Portugal corresponde a tipologias não antropomórficas. A maioria opta pelos contornos ovalados, como se observa em 139 exemplares $(36,6 \%)$, mas as sepulturas rectangulares e trapezoidais não se afastam muito destes valores, contando-se 115 exemplares das primeiras (30,3\%) e 82 das segundas $(21,6 \%)$. As sepulturas não antropomórficas cujos contornos são indeterminados totalizam 44 (11,6\%). Os sepulcros de configuração indeterminada são 265 , o que corresponde a $22,7 \%$ do conjunto das tumulações sem antropomorfismo.

A análise da distribuição das diferentes configurações das sepulturas pela tipologia de espaços funerários revela-nos que as sepulturas antropomórficas são sempre mais numerosas do que os sepulcros não antropomórficos, mantendo, porém, um certo equilíbrio representativo nos núcleos de sepulturas isoladas, nos núcleos de 2 a 5 e de 6 a 10 sepul- turas. As únicas situações em que se observa uma clara predominância de uma tipologia de sepultura sobre a outra, verifica-se nas necrópoles desordenadas e nas necrópoles associadas a templos, onde os monumentos de configuração antropomórfica predominam sobre as sepulturas que negam o antropomorfismo, sendo aproximadamente duas vezes mais numerosos (Gráfico 1). Aceitando que a polarização dos monumentos funerários em torno de templos é um acontecimento mais tardio, estes dados parecem confirmar que as tipologias não antropomórficas têm cronologias um pouco mais recuadas, embora continuem a ser utilizadas ao longo de todo o período cronológico em que se criaram sepulturas rupestres. Antes de entrarmos na análise da relação entre as estações com sepulturas escavadas na rocha e os elementos estruturadores do povoamento, como os locais de habitat, templos, fortificações ou vias de comunicação, devemos ressalvar que a bibliografia, na maioria das vezes, é omissa, não referindo directamente estas relações. Esta situação resulta do facto de, em demasiados casos, os estudos se contentarem com o estudo, de per se, das sepulturas, ignorando outros testemunhos ocupacionais, sobretudo se resumidos a vestígios arqueológicos (quer sejam cronologicamente coevos dos sepulcros, quer se situem, simplesmente, na sua proximidade física). Deste modo, e tendo em consideração que a sistematização realizada se alicerçou sobretudo em dados bibliográficos, as leituras que realizaremos de seguida deverão ser encaradas como provisórias, pois a realização de trabalhos de campo e de levantamentos arqueológicos mais sistemáticos certamente acrescentarão outras informações aos dados compilados (Quadro 2 e Mapa 4).

Feitas as devidas ressalvas, verificamos que 196 estações se encontram localizadas nas imediações de vestígios arqueológicos de habitat e/ou de templos, sendo esta associação mais frequente com os núcleos de 2 a 5 sepulcros e com sepulturas isoladas. Apesar de corresponder a apenas a pouco mais de metade das estações identificadas, o número de sepulturas que as integra é bastante elevado, sendo composto por 746 sepulcros. Mas não deixa de ser significativo, e tema para reflexão, o facto de esta associação ser tão representativa nestes grupos que correspondem a núcleos relativamente pequenos. Já vários estudos tinham sublinhado a articulação entre sepulcros isolados ou conjuntos de pequena dimensão e a matriz de povoamento, nomeadamen- 
te o cadastro de propriedades. Corresponderiam a uma fase em que os espaços de enterramento não estavam, ainda, polarizados em torno dos templos, sendo deixada às populações uma ampla margem de opção relativamente à eleição do local de sepultura.

A proximidade entre os espaços funerários e templos, áreas de habitat com templos ou a fortificações e templos corresponde a um total de 122 estações, cerca de $32 \%$, e a um conjunto de 477 sepulturas. Entre estas, as mais numerosas são as que se enquadram nas "Necrópoles associadas a templos", que correspondem a 31 estações e a 223 sepulturas e que Inãki Martin Viso relaciona com uma paisagem hierarquizada em que há uma memória comunitária gerida por uma instância de poder ${ }^{11}$.

A relação entre os sepulcros e as estruturas de cariz militar ou defensivo, como os povoados fortificados ou os castelos, tem uma representação muito pouco expressiva, resumindo-se apenas a 16 estações, constituídas no total por 6 o sepulturas. Igualmente residual é o número de locais associados exclusivamente a vias de comunicação. A implantação junto a caminhos e vias apenas se regista em 16 locais. A maioria destes espaços de enterramento é constituída por sepulturas isoladas (nove), por núcleos de 2 a 5 sepulturas (quatro casos), por núcleos de 6 a 10 sepulturas (dois casos) e por uma única necrópole desordenada. Mas, no seu conjunto totalizam apenas 55 sepulturas.

\section{PRIMEIROS RESULTADOS: LEITURAS PRELIMINARES}

Os dados apresentados sintetizam, de forma expressiva, um trabalho de prospeção e registo de uma área considerável do Norte de Portugal e do vale do Douro. Esta área geográfica, caracterizada por diferentes realidades geomorfológicas e de ocupação humana, corresponde a cerca de $23 \%$ da superfície de Portugal Continental. Nos dias de hoje, verifica-se uma maior densidade populacional na faixa atlântica, nomeadamente na região do Entre-Douro-e-Minho e um acentuado declínio demográfico nas terras do interior do país. A mesma assimetria verificar-se-ia também no decurso da Idade Média, sendo abundantes, na documentação medieval, os exemplos de atribuição de cartas de foral, de povoamento ou de privilégios a quem se fixasse no hinterland português.

11. Cf. Martin Viso, 2012, p. 172.
No total, falamos de um território com $20.388 \mathrm{~km}^{2}$, que apresenta um conjunto de 386 estações constituídas por 1.170 sepulturas escavadas na rocha. Isto equivale a um índice de 0,06 s.e.r. $/ \mathrm{km}^{2}$.

Em termos comparativos, Stuart Brookes, Catarina Tente e Sara Prata registaram no território de Viseu, e numa área de cerca de $6.150 \mathrm{~km}^{2}$, a existência de 522 estações com 1.726 sepulturas escavadas na rocha ${ }^{12}$. Corresponde a um índice de 0,28 s.e.r. $/ \mathrm{km}^{2}$, um valor bastante superior ao da região norte.

Ora, esta contabilidade coloca algumas perguntas sobre as quais importa reflectir. Desde logo, e olhando para a cartografia apresentada, notamos espaços vazios. Destes destacamos dois, procurando fundamentar essa realidade.

O primeiro é a zona costeira do território analisado, nomeadamente a região entre os rios Cávado e Ave, prolongando-se até às portas da cidade do Porto e estendendo-se para sul, para Vila Nova de Gaia, onde as estações com sepulcros rupestres são em reduzido número ou praticamente inexistentes. Na verdade, esta rarefacção ou ausência não se pode explicar por uma falta de pesquisas nesta região pois, desde cedo, ela tem merecido a atenção e o trabalho de diferentes investigadores ${ }^{13}$. Uma das causas poderá estar relacionada com a pressão urbana, bastante intensa nesta região, talvez responsável pela destruição de muitos vestígios, mesmo que nas últimas décadas, as políticas patrimoniais, enquadradas na arqueologia preventiva, tenham permitido salvaguardar muita informação. Contudo, não poderemos deixar de parte uma outra via de reflexão que explique a ausência de sepulturas escavadas na rocha em determinadas áreas, nomeadamente a opção por diferentes formas de inumação. Com efeito, a mancha geográfica das planícies do Minho, onde as sepulturas escavadas na rocha estão quase ausentes, corresponde a uma das áreas de maior densidade de sarcófagos não antropomórficos, lisos ou decorados com cruzes gregas páteas em relevo (na cabeceira e/ou nos pés), ou com os laterais apresentando decorações com arcaturas ou arquitecturas, alguns cobertos com tampas em estola, tudo materiais que correspondem ao período cronológico que se estende entre os séculos IX e XI/ XII. Neste sentido, a clara complementaridade entre a cartografia das sepulturas rupestres e a de estes sar-

12. Cf. Brookes, Tente \& Prata, 2017, p. 215.

13. Cf., por exemplo, Barroca, 1987, pp. 103-175; reeditado e actualizado em Barroca, 2010-11, pp. 115-182. 
cófagos, já realçada por um de nós, torna-se muito eloquente, revelando que, afinal, numa mesma época conviviam diferentes modalidades de enterramento, sujeitas a variabilidades de ordem geográfica e social ${ }^{14}$.

O segundo vazio evidente observa-se na região transmontana, particularmente na zona central onde, a par do relevo acidentado, sobressai o vale do rio Tua e os planaltos de Bragança e Miranda do Douro. Sobre esta extensa região faltam ainda trabalhos de investigação aprofundada, que analisem os dados existentes e acrescentem novos registos, permitindo propostas interpretativas devidamente fundamentadas. Mas parece evidente o contraste com a zona da falha tectónica Régua-Verín (que passa por Vila Real, Vila Pouca de Aguiar e Chaves), ou com o vale do Douro, a montante e a jusante do Marão ${ }^{15}$. Na região de Bragança e de Miranda os esforços têm recaído em trabalhos de levantamento, muitas vezes no âmbito da elaboração dos descritores dos planos directores municipais, integrando cartas arqueológicas onde as sepulturas escavadas na rocha são apenas mais um elemento patrimonial sumariamente mencionado e descontextualizado ${ }^{16}$. No entanto, não será apenas a escassez de trabalhos de investigação a justificar a inexistência de sepulturas escavadas na rocha. Lembramos que nesta região os solos são maioritariamente xistosos ou quartzíticos, materiais de fácil erosão, uns, ou de talhe difícil, outros, que podem ter levado as populações a procurar outras formas de enterramento. Por outro lado, as transformações económicas das últimas décadas alteraram de forma profunda a paisagem transmontana, povoando-a de extensas áreas de cultura intensiva de oliveira, castanheiros e vinha. Sabemos, por exemplo, que na região de Bragança a limpeza de largas extensões de terrenos tem destruído e danificado algum património arqueológico, onde se incluem necrópoles de variadas tipologias. Esta realidade, à qual não se poderá escapar, merece uma atenção urgente por parte das autoridades competentes e dos investigadores, de forma a ser assegurado o registo do património existente.

\footnotetext{
14. Barroca, 1987, pp. 177-251.

15. Para as sepulturas rupestres implantadas na zona da falha tectónica Régua-Verín vd. Almeida, 2009; Barroca \& Morais, 1983 e 1985-86; Teixeira, 1996; para o vale do Douro vd., entre outros, Lopes, 2002; Santos, 2005; e Guedes, 2015.

16. Para esta região vd. o estudo de Oliveira, 2020 (no prelo).
}

Uma segunda questão, que a aparente baixa densidade de sepulturas escavadas na rocha nesta região suscita, é se as comunidades terão, conscientemente, dado primazia a outras formas de enterramento, talvez mais "práticas" e económicas, como a inumação em fossas simples ou em sepulturas estruturadas com lajes ou pedras. Esta seria uma explicação válida para a falta de registos em zonas xistosas, independentemente de se registarem exemplos expressivos da sua existência, como acontece no caso da necrópole do Adro da Igreja de Mós (Torre de Moncorvo) com 39 sepulturas, das quais 21 são escavadas na rocha xistosa ${ }^{17}$, ou a necrópole da Igreja de Vila de Sinos (Mogadouro) intervencionada por Francisco Sande Lemos e Domingos dos Santos Marcos, que identificaram 69 sepulcros, tendo escavado 24 sepulturas das quais apenas oito eram escavadas exclusivamente no substrato rochoso ${ }^{18}$. Notamos que o distrito de Bragança, onde se regista um número reduzido de sepulturas escavadas na rocha, ocupa uma área de $6.608 \mathrm{~km}^{2}$, equivalente a $32 \%$ do total do território estudado e, mesmo contando com uma baixa taxa demográfica, continua a ser difícil explicar a falta de necrópoles rupestres em Trás-os-Montes. Observação idêntica poderá ser feita para a região litoral, que totaliza cerca de $7.500 \mathrm{~km}^{2}$, representado $37 \%$ do território analisado. Como já vimos, aqui o número de sepulcros rupestre é evidentemente baixo se considerarmos a densidade demográfica da região.

Voltando a analisar a cartografia, verificamos que a zona central do território estudado, correspondendo, grosso modo, ao distrito de Vila Real e Viseu, na margem sul do Douro, apresenta uma maior densidade de sepulturas escavadas na rocha, mesmo contando que se trata de uma região bastante acidentada, mas sobretudo granítica. Na verdade, se considerarmos a totalidade das estações, constatamos que cerca de $51 \%$ das sepulturas se implantam entre os 400 e os $800 \mathrm{~m}$ de altitude (Quadro 3), destacando-se as regiões de Montalegre, Vila Pouca de Aguiar e Lamego, onde existem estações a altitudes que rondam os $1.000 \mathrm{~m}$. Se os estudos conseguissem associar estas necrópoles aos elementos estruturadores do povoamento, como os locais de habitat, templos, fortificações ou vias de comunicação, poderíamos ter respostas para possíveis modelos de

17. Perpétuo, 2010.

18. Lemos e Marcos, 1985, pp. 142-143. 
assentamento, podendo, ao mesmo tempo, aferir de forma mais precisa cronologias para estes monumentos funerários.

Paralelamente a esta zona central, o vale do Douro, especialmente a margem direita, correspondente grosso modo aos concelhos de Penafiel, Marco de Canaveses, Amarante e Baião, agrupa um número considerável de sepulturas escavadas na rocha, existindo uma concentração bastante expressiva no curso final do rio Tâmega. Aqui as cotas de implantação das necrópoles são mais baixas e terão privilegiado zonas junto a possíveis áreas de exploração agrícola.

Efectivamente, a representação cartográfica demonstra que as necrópoles de sepulturas escavadas na rocha foram construídas preferencialmente ao longo das bacias hidrográficas, sobretudo ao longo dos cursos de água mais significativos, como os já referidos Douro e Tâmega, mas também dos rios Lima, Corgo, Tua e Sabor. A distribuição destes núcleos sepulcrais não obedece, aparentemente, a um padrão específico, pois nos rios Lima, Tâmega e Sabor existe uma maior concertação na zona terminal dos rios, enquanto que nos rios Douro e Corgo há uma "distribuição" ao longo das suas bacias, parecendo evitar-se as zonas da foz. O que parece claro é o facto de as linhas de água serem eixos estruturantes do território medieval, essenciais para a fixação de comunidades, mas também guias de orientação territoriais, onde o Douro tinha um papel primordial.

Finalmente, e porque o espaço de publicação nos obriga a ser sintéticos, importa atentar nas características gerais dos núcleos sepulcrais rupestres e questionarmo-nos sobre a sua relação com as estruturas de povoamento.

Os registos actuais dizem-nos que os espaços funerários são maioritariamente constituídos por sepulturas escavadas na rocha isoladas ou integradas em núcleos de 2 a 5 sepulturas, totalizando $63,7 \%$ dos sítios. No caso das sepulturas isoladas contabilizamos 121 sítios (31,3\%) e os núcleos de 2 a 5 sepulturas são $125(32,4 \%)$. As necrópoles constituídas por 6 a 1o monumentos correspondem a $8 \%$ do total, verificando-se a existência de 31 estações deste tipo. Estes são os dados. Se os pensarmos relacionados com o povoamento, e independentemente da sua distribuição geográfica e da sua cronologia, ocorrem-nos determinadas interrogações que o avanço da investigação pode aclarar.

Vejamos, por exemplo, as sepulturas isoladas e os pequenos grupos de 2 a 5 sepulturas, conjunto até agora maioritário. Que tipo de povoamento definem? Isolado, próprio de comunidades com alguns recursos económicos, que vivem da exploração agrícola, em zonas profundamente parceladas e trabalhadas por dependentes? Ou concentrado, em pequenas comunidades familiares (ou não), talvez "independentes", mas ligadas entre si por fortes laços de solidariedade, que garantiam a sobrevivência do grupo? E como se articularia cada uma destas comunidades com os locais de culto? Teriam "igreja própria" ou estavam agregadas em paróquias mais amplas que, pela sua extensão territorial, permitiam a existência de vários espaços de enterramento no interior do seu âmbito geográfico? Sendo assim, a escolha de local de sepultura, próximo dos seus, seria uma opção preferível? Para os pequenos proprietários, seria uma forma de legitimação de direitos fundiários? Temos vários indícios, ao longo da plena Idade Média, de que a presença de sepulcros de antepassados foi encarada como forma de sancionar direitos hereditários...

As inumações junto a templos são facilmente compreensíveis para comunidades, talvez mais numerosas, multifamiliares, concentradas em povoações que exploram determinado território sob orientação de um poder. Este tipo de assentamento deu origem a núcleos sepulcrais mais extensos. Mas eles são relativamente raros na zona que estudámos. Esta observação tem evidente implicação cronológica. Significa que a implantação do modelo paroquial resultante da reforma gregoriana - que impôs que, dentro do espaço de uma paróquia, existisse um único templo apto a ministrar os sacramentos de passagem (baptismo, casamento, funeral), que existisse um único ministro da Igreja apto para os ministrar (o pároco), que existisse um único templo com pia baptismal e que existisse um único espaço de enterramento (o adro da igreja) - surgiu numa fase em que a "moda" das sepulturas escavadas na rocha estava a entrar em declínio. Por isso, os exemplos de necrópoles rupestres estruturadas em torno de adros de templos paroquiais parece ser uma opção residual. E, pelo contrário, as sepulturas estruturadas com lajes, são muito mais comuns. A menos que, futuras intervenções arqueológicas venham aduzir novos dados para esta problemática...

Outro aspecto interessante relaciona-se com a personalização, ou não, dos enterramentos. Já muitos autores sublinharam o anonimato das sepulturas rupestres, para as quais não se conhece qualquer 
exemplo de epitáfio ${ }^{19}$. Esta aparente ausência de preocupação em registar a identidade do defunto poderá estar relacionada com o facto de, nessa altura, ainda não se ter difundido o conceito que atribuía às orações o poder de intercessão no destino das almas no Além. Isso implica aceitar que, durante uma boa parte do período em que se criaram sepulturas rupestres, ainda não haveria comemorações obituárias por alma do defunto, e portanto, como não se tinha de ir sobre a sua sepultura, esta apresentava-se despida de elementos identificadores. Mas existe um pequeno conjunto de sepulcros que começam a denunciar a preocupação de o individualizar. Referimo-nos às sepulturas escavadas na rocha que apresentam encaixes para estelas discoides. Na zona que estudámos isso ocorre em 10 casos (nove com encaixe para uma estela, na zona da cabeceira; um com duplo encaixe, na cabeceira e pés). O seu valor percentual é insignificante ( $0,9 \%)$, mas a sua importância é grande.

Um último, e necessariamente breve, apontamento para analisar a problemática em torno da orientação dos sepulcros. Este é um tema complexo, que não podemos explorar integralmente neste traba1ho. O quadro que apresentamos de seguida (Quadro 4) sistematiza os principais dados alcançados, subdividindo-os por quadrantes de orientação dos sepulcros. Subdividimos os $360^{\circ} \mathrm{em}$ oito categorias - os quatro pontos cardiais e os seus pontos intermédios - obtendo, assim, grupos com $45^{\circ}$ de amplitude. Subdividimos cada grupo pelo ponto médio com o precedente e o seguinte. Ou seja, consideramos como quadrante Norte todos os valores obtidos entre os $337,6^{\circ}$ e os $22,5^{\circ}$, tendo como valor médio os $\mathrm{O}^{\circ}$ equivalentes a Norte. $\mathrm{E}$ assim sucessivamente. Esta sistematização - que não impede que os dados precisos, sempre que eles existam, estejam arrolados na Base de Dados - permitiu definir grandes categorias, tornando-as comparáveis. Como se pode verificar, a maioria das sepulturas escavadas na rocha encontra-se orientada com cabeceira voltada para Oeste (244 exemplos, 21\%). Há um conjunto, igualmente significativo, de sepulcros com a cabeceira orientada para o quadrante de Noroeste (111 sepulcros, 10\%). O que significa que, se tivermos em consideração a oscilação do curso solar ao longo do ano, entre os dois solstícios, teremos mais de um terço das sepulturas cultualmente orientadas. Este dado é interessante porque, como se sabe, a Igreja só muito tardiamente justificou a orientação do sepulcro cristão. O que quer dizer que este hábito se afirmou independentemente das directrizes da hierarquia da Igreja. Mas é igualmente muito expressivo o grupo de sepulcros que tem uma orientação diametralmente oposta, ou seja, que apresenta a cabeceira orientada para Leste (são 159 sepulturas, equivalentes a 14\%). É mesmo o segundo alinhamento mais comum no Norte de Portugal e Vale do Douro. Esta orientação sepulcral inversa pode ter implicações religiosas e/ou sociais. Já vários autores sugeriram que ela seria um sintoma de práticas sociais marginais, condenadas pela sociedade e pela Igreja. As mesmas que levariam à inumação em decubito prono, em vez da prática, esmagadoramente predominante, do enterramento em decubito supino. Mas não temos dados seguros para defender esse tipo de interpretações, que mais não passam de hipóteses. Poderiam ser, quiçá, o resultado de alguma confusão no conceito da orientação cultual do enterramento, optando-se por colocar a cabeça voltada para Leste, para Jerusalém. O que merece ser sublinhado é que as orientações pelo curso solar - seja com a cabeceira voltada para Oeste, seja com a cabeceira virada para Leste - são claramente predominantes. E que as orientações diametralmente opostas - viradas para Norte ou para Sul - parecem corresponder a uma franja marginal, quase inexpressiva (com 5 e $3 \%$, respectivamente). Vale a pena, igualmente, cruzar os dados da orientação dos sepulcros com os indicadores tipológicos. Aqui, encontramos um persistente equilíbrio: $52,9 \%$ das sepulturas orientadas para Oeste são antropomórficas, e 35,7\% são não antropomórficas; $57,2 \%$ das sepulturas orientada para Leste são antropomórficas, e 33,3\% são não antropomórficas. Confessamos que a nossa impressão era que o conjunto de sepulturas não antropomórficas seria mais receptivo a ter orientações não cultuais, e o que estes dados nos revelam é que o comportamento é sensivelmente equivalente. Por fim, registemos que estes dados ajudam a sublinhar a necessidade de se registar, com rigor, a orientação axial de todos os sepulcros, não apenas numa orientação genérica, por quadrante, mas em graus, com recurso a bússola. Só esses dados permitem tratamento mais fino.

19. Barroca, 2010, p. 437. 


\section{CONCLUSÃO}

Com a implementação do projecto "Sepulturas Escavadas na Rocha do Norte de Portugal e do Vale do Douro" começou a ser construído um novo instrumento de pesquisa que, conforme previamente explicitado, se articula com um outro, em curso, para o Centro do território português. Focados, pois, em áreas geográficas distintas, assumem-se, a este nível, como complementares, mas simultaneamente, como potenciadores de leituras não necessariamente coincidentes ou unívocas.

Com efeito, a própria mancha de ocorrências inventariadas e cartografadas denota variáveis expressivas em termos quantitativos, circunstância que é em si mesma ilustrativa da ausência de um padrão único de implementação e, eventualmente, até da existência de graus distintos de adesão a este tipo singular de prática funerária.

Todavia, também os dados recolhidos no âmbito do projecto SER-NPVD, e que sumariamente se apresentam e discutem nos pontos 3 e 4 deste texto, evidenciam a vigência de assimetrias no próprio interior do território em análise. Assimetrias que, como demonstrado, poderão estar correlacionadas com múltiplos factores, naturais e humanos, em si mesmos igualmente indissociáveis. Consideremos, por exemplo, as especificidades do substrato geológico, do relevo, a proximidade de cursos fluviais ou de vias, ou a articulação das áreas de habitat com um eventual templo agregador da comunidade. Vectores que, necessariamente, se impõe examinar e articular não apenas com as particularidades morfológicas dos enterramentos, mas também com a prevalência das ocorrências documentadas: isoladas, em núcleos de 2 a 5 sepulturas ou integradas em efectivas necrópoles.

A compilação dos dados que têm vindo a ser recolhidos não é isenta de constrangimentos. De facto, e apenas para retomar um dos pontos já evocados, a bibliografia disponível e sistematicamente consultada espelha uma ampla diversidade de inquéritos e métodos de abordagem ao terreno, os quais, inevitavelmente, condicionam a própria profundidade e pormenor das informações veiculadas. De igual modo, a existência de programas de investigação direccionados para unidades geográficas específicas é susceptível de permitir um arrolamento rigoroso das sepulturas rupestres conservadas, potenciando um mapeamento numericamente significativo.
Em contrapartida, os "vazios" detectados poderão, ou não, reflectir uma efectiva ausência ou escassez deste tipo de testemunho material. Não obstante, e sendo certo que a construção das bases de dados do projecto SER-NPVD configura um desafio a vários níveis, inclusivamente também devido à extensão do território por ele abarcado, não temos dúvidas de que representa também um veículo determinante para a abertura de possibilidades de análise, questionamento e interpretação de um fenómeno ainda insuficientemente compreendido e que, neste sentido, continua a interpelar os investigadores.

\section{BIBLIOGRAFIA}

ALMEIDA, Joana Filipa Tuna de (2009) - Sepulturas escavadas nas rochas no Concelho de Vila Real. In Tellus. Vila Real. 50, pp. 39-68.

AREZES, Andreia (2020) - Sepulturas escavadas na rocha no curso inferior da bacia do rio Lima. O concelho de Viana do Castelo em perspectiva. In M. J. Barroca (Coord.), Congresso Internacional Sepulturas escavadas na rocha na Fachada Atlântica da Península Ibérica. Porto. CITCEM (no prelo).

BARROCA, Mário Jorge; MORAIS, António J. C. (1983) Sepulturas Medievais na Terra de Aguiar da Pena (Vila Pouca de Aguiar). In Arqueologia. 8, pp. 92-102.

BARROCA, Mário Jorge; MORAIS, António J. C. (1985-86) - A Terra e o Castelo. Uma experiência arqueológica em Aguiar da Pena. In Portvgalia. Porto. 6-7, pp. 35-88.

BARROCA, Mário Jorge (1987) - Necrópoles e Sepulturas Medievais de Entre-Douro-e-Minho (Séculos V a XV). Porto: Faculdade de Letras da Universidade do Porto.

BARROCA, Mário Jorge (2010) - Memórias. In J. Mattoso (Dir. de) e B. V. Sousa (Coord. de), História da Vida Privada em Portugal. vol. 1. Lisboa, Círculo de Leitores, pp.418-456.

BARROCA, Mário Jorge (2010-2011) - Sepulturas escavadas na rocha de Entre Douro e Minho. In Portvgalia. Porto. 31-32, pp. 115-182.

BARROCA, Mário Jorge (2020) - Os estudos sobre sepulturas escavadas na rocha em Portugal, trinta anos depois. In M. J. Barroca (Coord.), Congresso Internacional Sepulturas escavadas na rocha na Fachada Atlântica da Península Ibérica. Porto. CITCEM (no prelo).

BROOKES, Stuart; TENTE, Catarina; PRATA, Sara (2017) - Interpreting Rock-Cut Grave Cemeteries: The Early Medieval Necropolis and Enclosure of São Gens, Portugal. In Medieval Archaeology. 61:2, pp. 215-238. DOI: 10.108o/oo766 097.2017.1374093.

GUEDES, César (2015) - A sul do Douro: percurso pelas sepulturas escavadas na rocha entre os rios Távora e Cabrum. Porto: Faculdade de Letras da Universidade do Porto, Porto. Tese de Mestrado. 
GUEDES, César (2020) - As sepulturas escavadas na rocha entre os rios Távora e Cabrum. Tipologias, implantação e as leituras possíveis do território. In M. J. Barroca (Coord.), Congresso Internacional Sepulturas escavadas na rocha na Fachada Atlântica da Península Ibérica. Porto. CITCEM (no prelo).

LEMOS, Francisco Sande (1993) - Povoamento Romano de Trás-os-Montes Oriental. Braga: Universidade do Minho. Tese de Doutoramento.

LEMOS, Francisco Sande e MARCOS, Domingos dos Santos (1985) - A necrópole medieval de Vila dos Sinos - Mogadouro Segunda Campanha de Escavações, 1982. In Cadernos de Arqueologia. Braga: Unidade de Arqueologia da Universidade do Minho - Museu D. Diogo de Sousa. Série II, Vol. 2. pp. 127-156.

LOPES, Isabel Alexandra Resende Justo (2002) - Contextos Materiais da Morte durante a Idade Média: as Necrópoles do Douro Superior. Porto: Faculdade de Letras da Universidade do Porto. Tese de Mestrado.

MARTIN VISO, Iñaki (2012a) - Enterramientos, memoria social y paisaje en la alta edad media: propuestas para un análisis de las tumbas excavadas en roca en el centro oeste de la Península Ibérica. In Zephyrus. LXIX, pp. 165-187.

MARTIN VISO, Iñaki (2012b) - Paisajes sagrados, paisajes eclesiásticos: de la necrópolis a la parroquia en el Centro de la Península Ibérica. In Reti Medievali Rivista. 13(2). Firenze, pp. 2-45 (disponível em http://rivista.retimedievali.it).

MARTIN VISO, Iñaki (2016) - Comunidades locales, lugares centrales y espácios funerários en la Extremadura del Duero medieval: Las necrópolis de tumbas excavadas en la roca alienadas. In Anuário de Estudios Medievales. Barcelona. 46(2). pp. 859-897.
OLIVEIRA, Ana Maria (2020) - Sepulturas escavadas na rocha da região de Bragança: contributo para o estudo do povoamento medieval. In M. J. Barroca (Coord.), Congresso Internacional Sepulturas escavadas na rocha na Fachada Atlântica da Península Ibérica. Porto. CITCEM (no prelo).

PEREIRA, Sofia (2015) - Inventário e Georreferenciação do mundo funerário rupestre no Centro de Portugal. Lisboa, UNL-FCSH. Relatório de Estágio.

PERPÉTUO, João Miguel André (2010) - Adro da Igreja de Mós - Escavação Arqueológica, Preservação e Acondicionamento (Mós-Torre de Moncorvo). Viseu: Arqueohoje Lda. Relatório policopiado.

SANTOS, Maria José Ferreira dos (2005) - A Terra de Penafiel na Idade Média. Estratégias de Ocupação do Território (875-1308). In Cadernos do Museu. Penafiel: Museu Municipal de Penafiel. 10.

TENTE, Catarina (2015) - Tumbas rupestres en el Alto Mondego (Guarda, Portugal). Patrones de distribución, significados y construcción del paisaje rural altomedieval. In Munibe Antropologia-Arkeologia. Bilbao. 66, pp. 271-29o.

TENTE, Catarina (2017) - Rock-cut graves and cemeteries in the medieval rural landscape of the Viseu region (central Portugal). In C. Theune-Vogt e C. Bis-Worch (Eds.), Religious places, cult and rituals in medieval rural environment, Leiden. pp. 215-226.

TEIXEIRA, Ricardo (1996) - De Aquae Flaviae a Chaves. Povoamento e organização do território entre a Antiguidade e a Idade Média. Porto: Faculdade de Letras da Universidade do Porto. Tese de Mestrado. 


\begin{tabular}{|c|c|c|c|}
\hline Distrito & Municípios & Freguesias* & Área \\
\hline Viana do Castelo & $\begin{array}{l}\text { 1o (Arcos de Valdevez; Caminha; Melgaço; Monção; Paredes } \\
\text { de Coura; Ponte da Barca; Ponte de Lima; Valença do Minho; } \\
\text { Viana do Castelo; Vila Nova de Cerveira) }\end{array}$ & 290 & $2.255 \mathrm{~km}^{2}$ \\
\hline Braga & $\begin{array}{l}14 \text { (Amares; Barcelos; Braga; Cabeceiras de Basto; Celorico de Basto; } \\
\text { Esposende; Fafe; Guimarães; Póvoa de Lanhoso; Terras de Bouro; } \\
\text { Vieira do Minho; Vila Nova de Famalicão; Vila Verde; Vizela) }\end{array}$ & 519 & $2.706 \mathrm{~km}^{2}$ \\
\hline Porto & $\begin{array}{l}18 \text { (Amarante; Baião; Felgueiras; Gondomar; Lousada; Maia; Marco } \\
\text { de Canaveses; Matosinhos; Paços de Ferreira; Paredes; Penafiel; Porto; } \\
\text { Póvoa de Varzim; Santo Tirso; Trofa; Valongo; Vila do Conde; Vila } \\
\text { Nova de Gaia) }\end{array}$ & 393 & $2.395 \mathrm{~km}^{2}$ \\
\hline Vila Real & $\begin{array}{l}14 \text { (Alijó; Boticas; Chaves; Mesão Frio; Mondim de Basto; Montalegre; } \\
\text { Murça; Peso da Régua; Ribeira de Pena; Sabrosa; Santa Marta de } \\
\text { Penaguião; Valpaços; Vila Pouca de Aguiar; Vila Real) }\end{array}$ & 268 & $4.328 \mathrm{~km}^{2}$ \\
\hline Bragança & $\begin{array}{l}12 \text { (Alfândega da Fé; Bragança; Carrazeda de Ansiães; Freixo de } \\
\text { Espada à Cinta; Macedo de Cavaleiros; Miranda do Douro; Mirandela; } \\
\text { Mogadouro; Torre de Moncorvo; Vila Flor; Vimioso; Vinhais) }\end{array}$ & 299 & $6.608 \mathrm{~km}^{2}$ \\
\hline Aveiro & 2 (Castelo de Paiva e, de Santa Maria da Feira, apenas a freg. de Canedo) & 10 & $144 \mathrm{~km}^{2}$ \\
\hline Viseu & 6 (Armamar; Cinfães; Lamego; Resende; S. João da Pesqueira; Tabuaço) & 115 & $1.045 \mathrm{~km}^{2}$ \\
\hline Guarda & 2 (Figueira de Castelo Rodrigo; Vila Nova de Foz Côa) & 34 & $907 \mathrm{~km}^{2}$ \\
\hline TOTAIS & 78 & 1.928 & $20.388 \mathrm{~km}^{2}$ \\
\hline
\end{tabular}

Quadro 1

* Para o SER-NPVD consideramos a organização administrativa anterior à reforma de 2013, pelo facto de ela se aproximar mais da organização paroquial medieval. Por isso, o número de freguesias apresenta-se mais elevado do que o actualmente em vigor.

\begin{tabular}{|c|c|c|c|c|c|c|c|c|c|c|c|}
\hline \multirow[b]{2}{*}{ Espaço Funerário } & \multicolumn{11}{|c|}{ Articulação com a paisagem } \\
\hline & 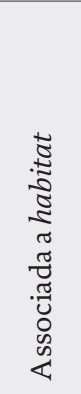 & 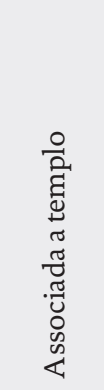 & 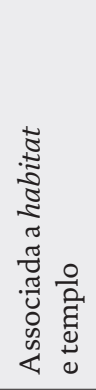 & 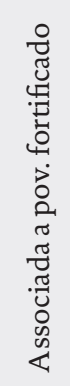 & 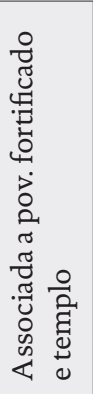 & 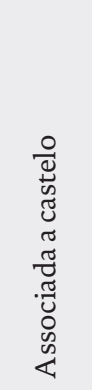 & 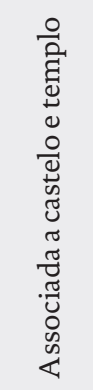 & 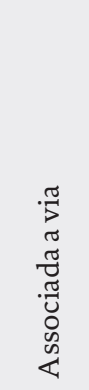 & 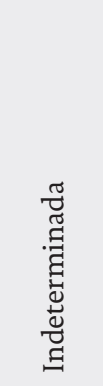 & Total & $\%$ \\
\hline Sepultura isolada & 19 & 19 & 6 & 1 & 2 & o & 1 & 9 & 64 & 121 & $31,3 \%$ \\
\hline N. de 2 a 5 sepulturas & 44 & 17 & 10 & $\mathrm{o}$ & 2 & o & 2 & 4 & 46 & 125 & $32,4 \%$ \\
\hline N. de 6 a 10 sepulturas & 14 & 4 & 2 & 1 & $\mathrm{o}$ & 1 & $\mathrm{o}$ & 2 & 7 & 31 & $8 \%$ \\
\hline Nec. Desordenada & 2 & 3 & 1 & o & o & $\mathrm{o}$ & 1 & 1 & 4 & 12 & $3,1 \%$ \\
\hline Nec. associada a templo & - & 27 & 3 & $\mathrm{o}$ & o & o & 1 & o & o & 31 & $8 \%$ \\
\hline Indeterminado & 6 & 12 & 7 & 2 & 1 & o & 1 & o & 37 & 66 & $17,1 \%$ \\
\hline Total & 85 & 82 & 29 & 4 & 5 & 1 & 6 & 16 & 158 & 386 & $100 \%$ \\
\hline$\%$ & $22 \%$ & $21,2 \%$ & $7,5 \%$ & $1 \%$ & $1,3 \%$ & $0,3 \%$ & $1,6 \%$ & $4,1 \%$ & $40,9 \%$ & $100 \%$ & \\
\hline
\end{tabular}

Quadro 2 


\begin{tabular}{|l|c|c|}
\hline Altitude & N.. de Estações & Percentagem \\
\hline o-99 m & 22 & $5,7 \%$ \\
\hline $100-199 \mathrm{~m}$ & 33 & $8,5 \%$ \\
\hline $200-299 \mathrm{~m}$ & 34 & $8,8 \%$ \\
\hline $300-399 \mathrm{~m}$ & 35 & $9,1 \%$ \\
\hline $400-499 \mathrm{~m}$ & 27 & $7,0 \%$ \\
\hline $500-599 \mathrm{~m}$ & 45 & $11,7 \%$ \\
\hline $600-699 \mathrm{~m}$ & 74 & $19,2 \%$ \\
\hline $700-799 \mathrm{~m}$ & 50 & $13,0 \%$ \\
\hline $800-899 \mathrm{~m}$ & 24 & $6,2 \%$ \\
\hline $900-999 \mathrm{~m}$ & 12 & $3,1 \%$ \\
\hline$>1000 \mathrm{~m}$ & 6 & $1,6 \%$ \\
\hline Ind. & 24 & $6,2 \%$ \\
\hline Total & 386 & $100,0 \%$ \\
\hline
\end{tabular}

Quadro 3

\begin{tabular}{|l|c|c|c|c|c|}
\hline Orientação & Antropomórficas & Não Antropomórficas & Indeterminadas & Total & $\%$ \\
\hline $\mathrm{N}\left(337,6^{\circ}-22,5^{\circ}\right)$ & 28 & 24 & 1 & 53 & $5 \%$ \\
\hline $\mathrm{NE}\left(22,6^{\circ}-67,5^{\circ}\right)$ & 11 & 37 & 2 & 50 & $4 \%$ \\
\hline $\mathrm{E}\left(67,5^{\circ}-112,5^{\circ}\right)$ & 91 & 53 & 15 & 159 & $14 \%$ \\
\hline $\mathrm{SE}\left(112,6^{\circ}-157,5^{\circ}\right)$ & 7 & 16 & 0 & 23 & $2 \%$ \\
\hline $\mathrm{S}\left(157,6^{\circ}-202,5^{\circ}\right)$ & 17 & 14 & 3 & 34 & $3 \%$ \\
\hline $\mathrm{SW}\left(202,6^{\circ}-247,5^{\circ}\right)$ & 41 & 27 & 28 & 72 & $6 \%$ \\
\hline $\mathrm{W}\left(247,6^{\circ}-292,5^{\circ}\right)$ & 129 & 87 & 1 & 244 & $21 \%$ \\
\hline $\mathrm{NW}\left(292,6^{\circ}-337,5^{\circ}\right)$ & 62 & 48 & 211 & 411 & $10 \%$ \\
\hline Indeterminada & 139 & 74 & 265 & 1170 & $100 \%$ \\
\hline Total & 525 & 380 & & & $36 \%$ \\
\hline
\end{tabular}

Quadro 4

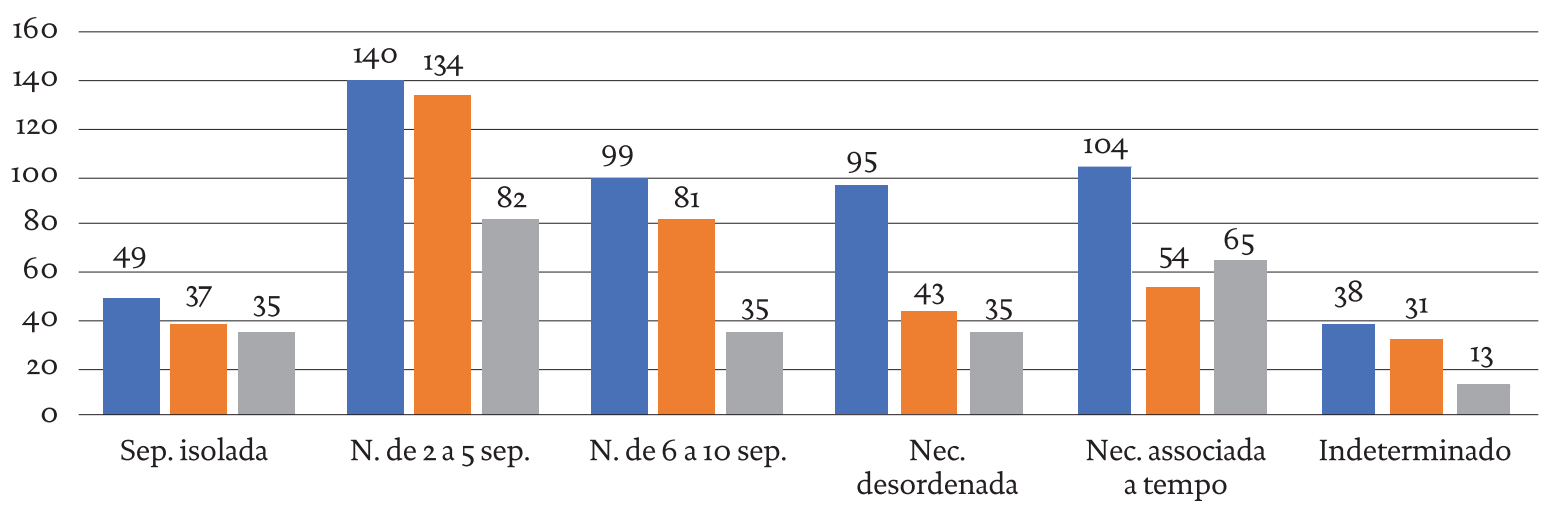

antropomórfica $\quad$ Não antropomórfica $\quad$ Indeterminada

Gráfico 1 - Distribuição das diferentes tipologias de sepultura pelos espaços funerários. 


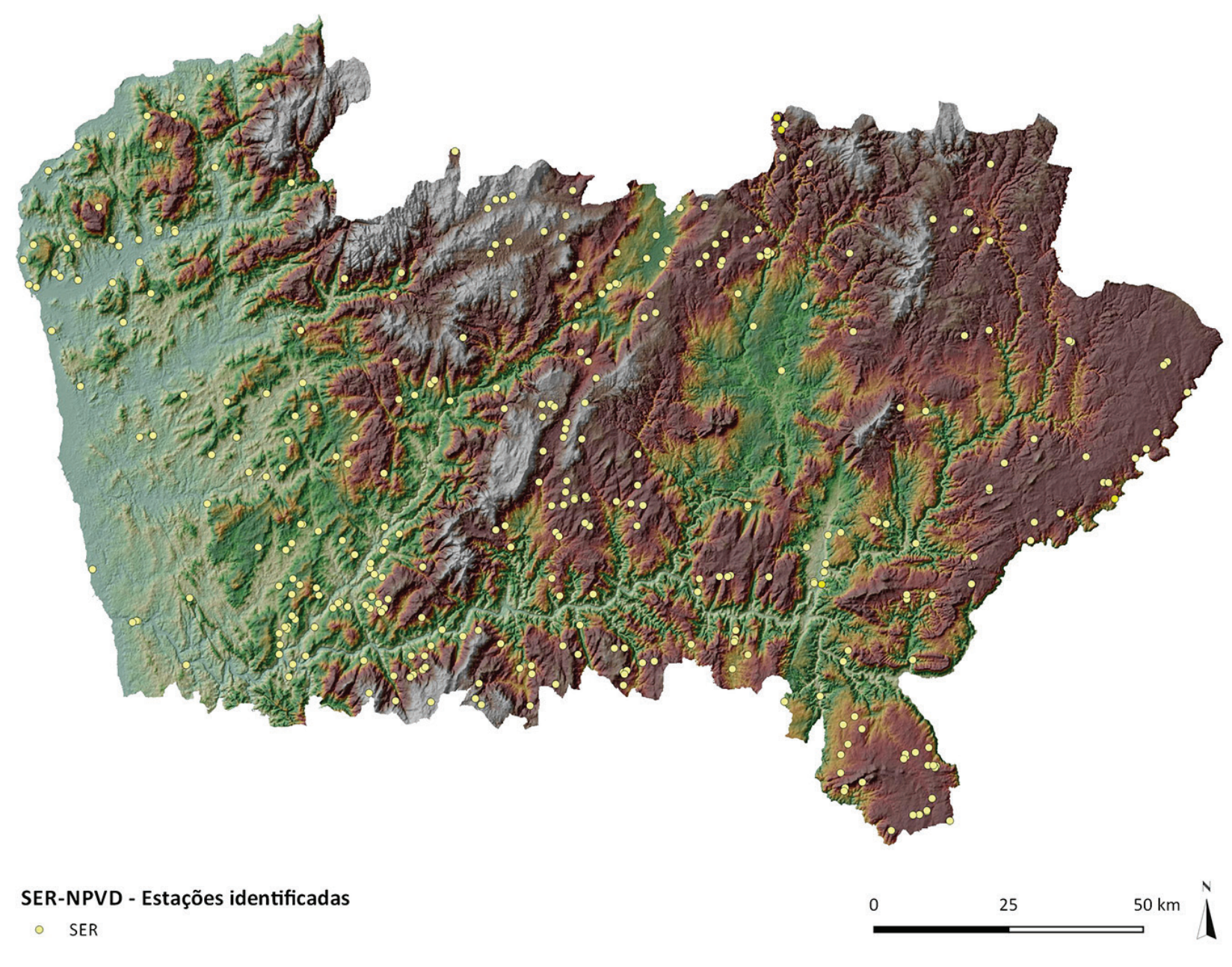

Mapa 1 - Área de estudo e distribuição das estações identificadas no âmbito do SER-NPVD. Autor: César Guedes. 


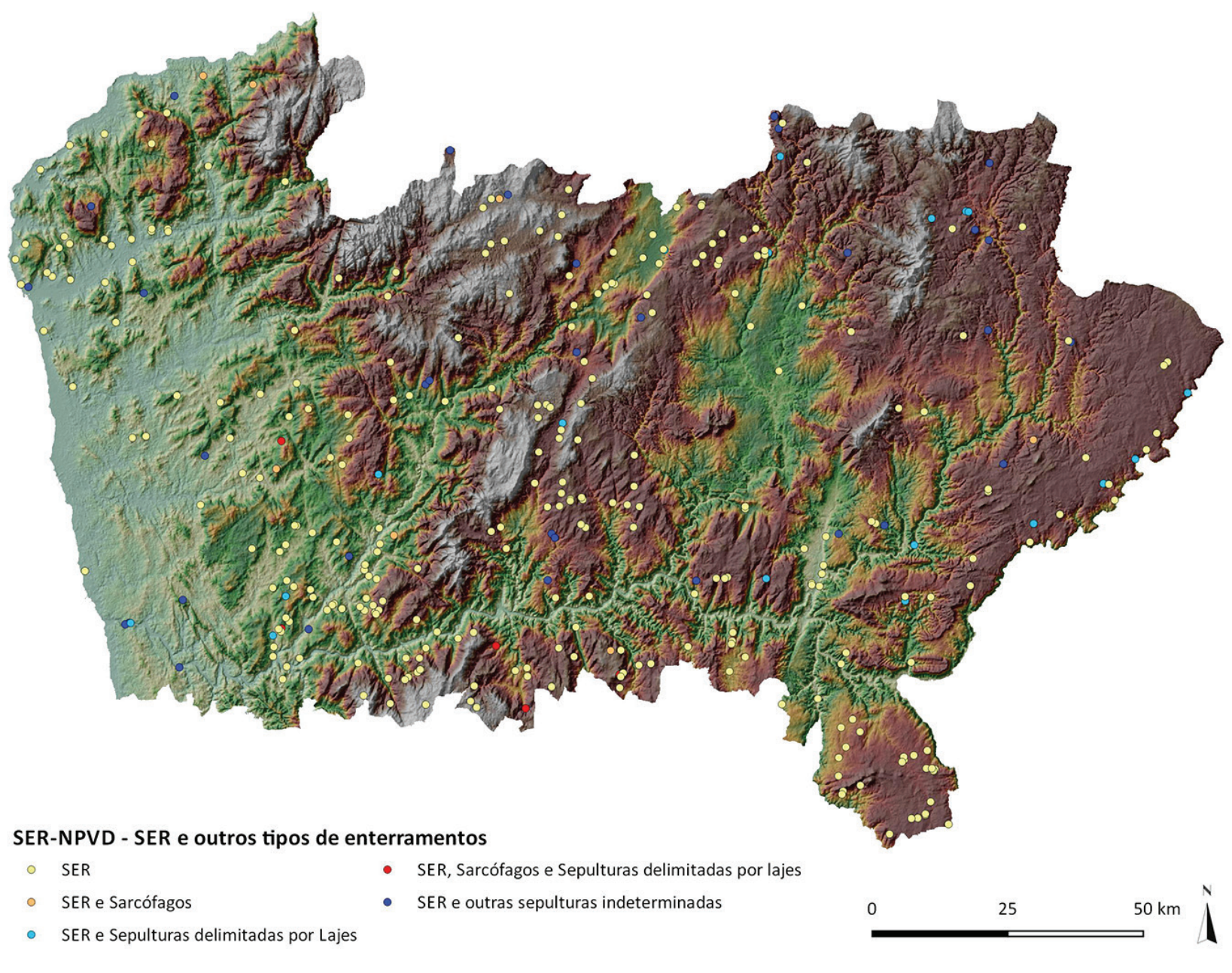

Mapa 2 - Distribuição das estações com sepulturas escavadas na rocha e outros tipos de enterramentos. Autor: César Guedes. 


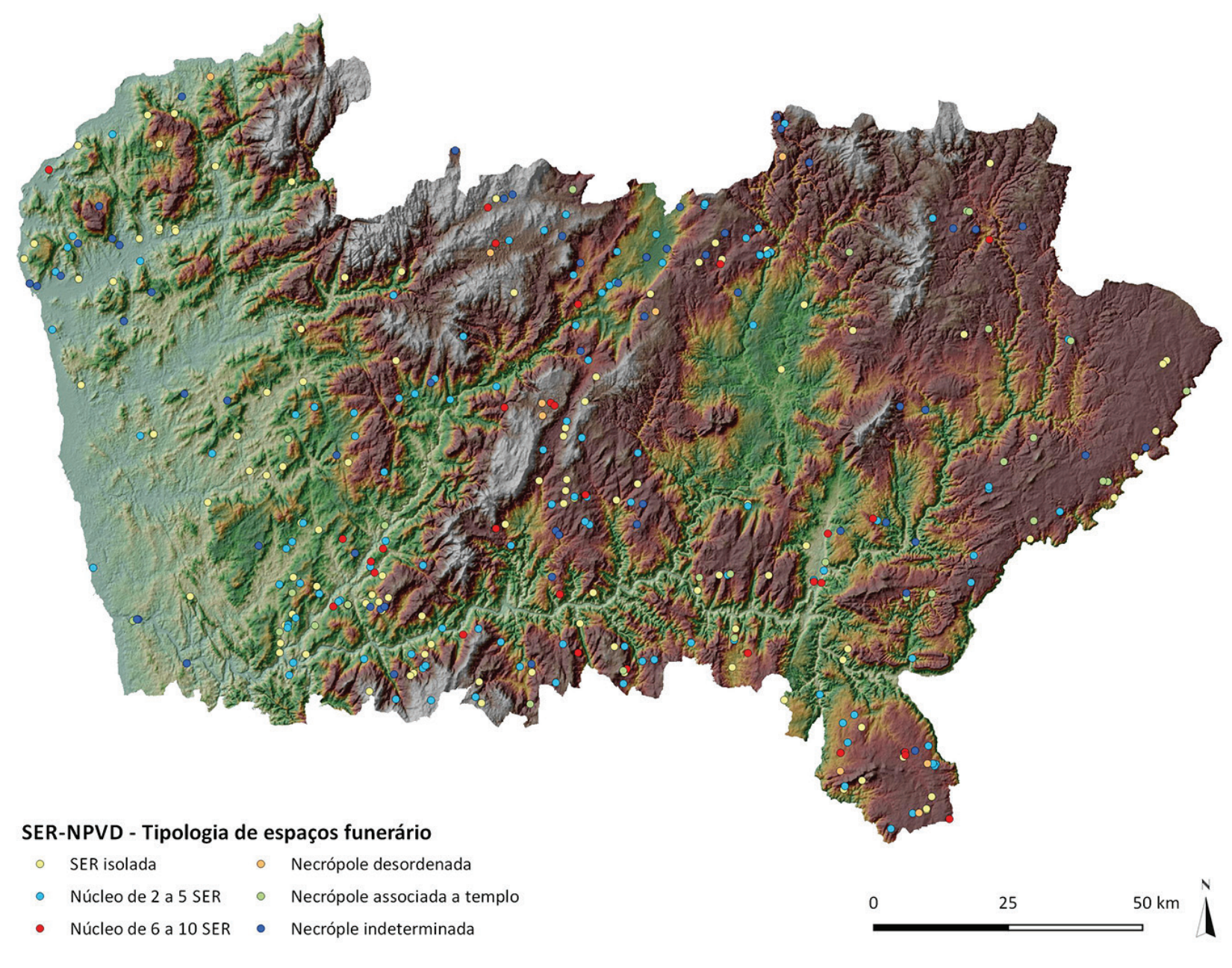

Mapa 3 - Tipologia dos espaços funerários. Autor: César Guedes. 


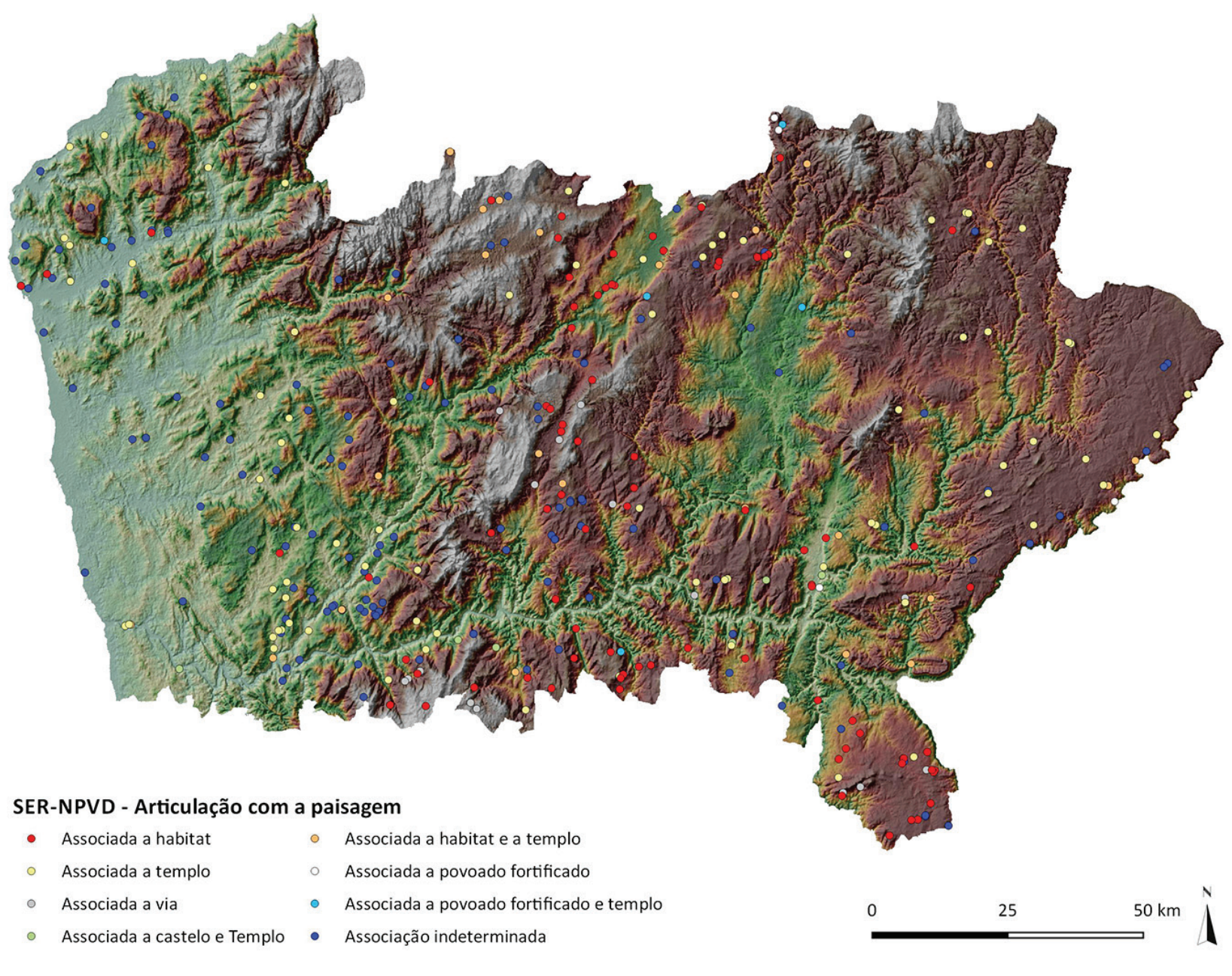

Mapa 4 - Articulação entre as estações com sepulturas escavadas na rocha e a paisagem. Autor: César Guedes. 


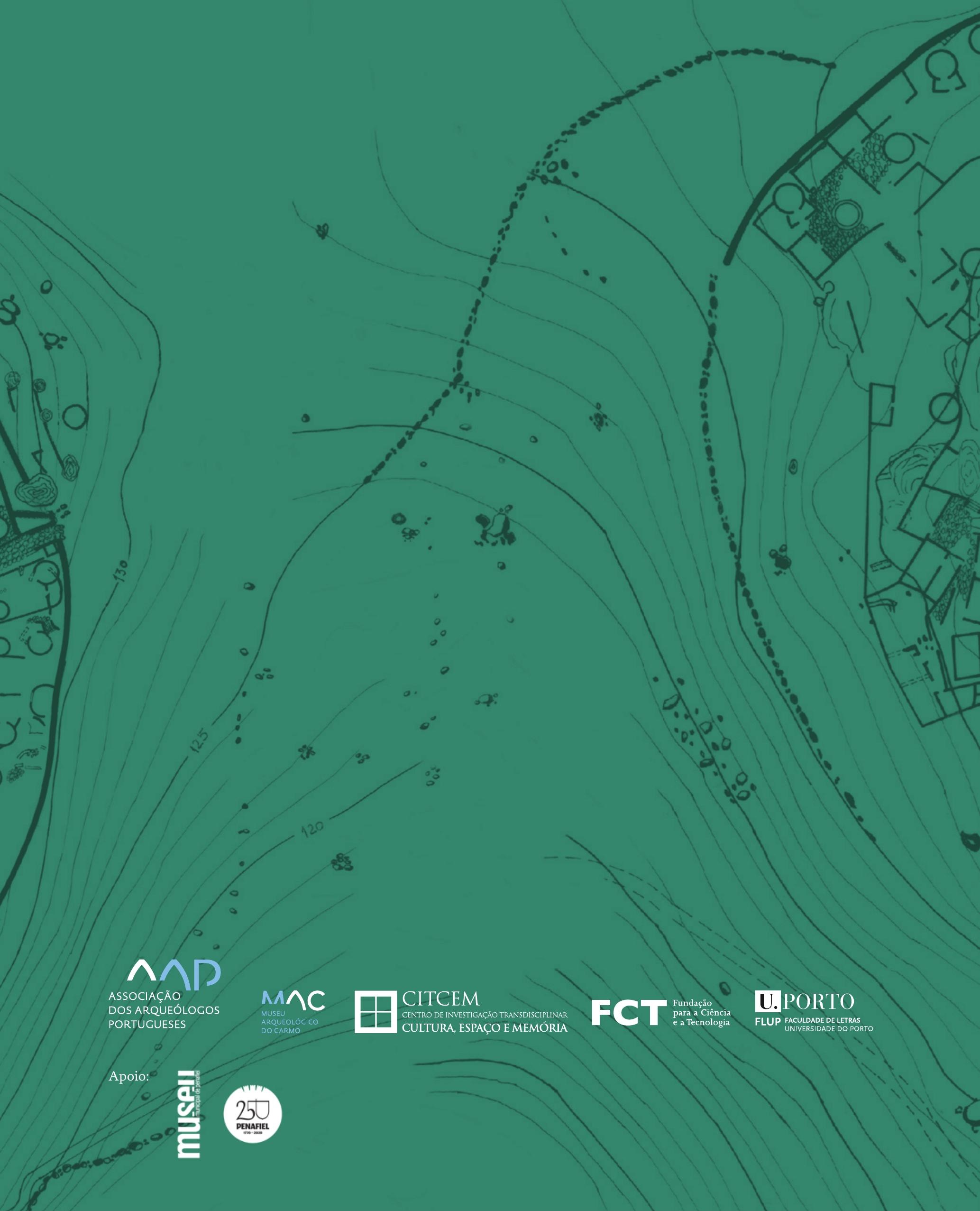

